\title{
Culture and the social-ecology of local food use by Indigenous communities in northern North America
}

\author{
Roxanne Tremblay $^{1}$, Manuelle Landry-Cuerrier $^{1}{ }^{\text {and Murray M. Humphries }}{ }^{1}$
}

\begin{abstract}
Social-ecological and biocultural systems connect people to their environment at the intersection of nature and culture. The harvest of local wildlife for human consumption is critically important to the food security of the world's Indigenous peoples and to the conservation of biodiversity, either as a driver of biodiversity loss or of biodiversity protection, depending on system properties. By their nature, local food systems are assumed to be both ecologically determined and culturally defined. Here, we analyze standardized local food consumption surveys conducted in 21 Indigenous communities across northern North America. Using measures of dietary similarity from the ecological sciences and a variance partitioning statistical approach, we reveal a profound and prevailing importance of culture in defining the types and amounts of animal species consumed as food, operating within the environmental constraint of local availability. This quantitative, multicommunity analysis reveals the sustainability and cultural agency inherent in local food systems and the importance of cultural-ecological coupling in an era of accelerating social and environmental change.
\end{abstract}

Key Words: biodiversity; country food; cultural diversity; food systems; Indigenous peoples; traditional food; trophic niche

\section{INTRODUCTION}

Social-ecological and biocultural systems connect people to their environment at the intersection of nature and culture (Marsh 1864, Loh and Harmon 2005, Moran 2016). The multiple modalities coupling human and natural systems have been long and deeply explored within environmental (or ecological) anthropology, most often using ethnographic methods best suited to studies of local, community-scale connections (Orr et al. 2015). Across different disciplines and at various scales, many other approaches have been used to highlight the form and extent of this coupling, including ecosystem services (Díaz et al. 2015), natural capital accounting (Ekins et al. 2003), social-ecological frameworks (Ostrom 2009) and models (Schlüter et al. 2014), and the human geology of the Anthropocene (Lewis and Maslin 2015). Nevertheless, systematic, multicommunity indicators of biocultural coupling, such as the demonstrated co-occurrence of linguistic and biological diversity (Gorenflo et al. 2012), remain rare.

Conceptualizing people and the environment as distinct or separable entities is especially incommensurate with the worldviews of many Indigenous peoples, whose traditional knowledge, though diverse and ever-changing, emphasizes relationships between human and nonhuman life and between the animate and inanimate worlds (Berkes 2012). Ecological connections, sentience, and communication among diverse entities are prioritized (Semali and Kincheloe 2002) in a manner that respects differences and diversity while maintaining the possibility of communication and codependency (Kohn 2007). Expressed another way, Indigenous peoples view themselves and nature as part of an extended ecological family who share ancestry, origins, and interdependencies (Salmón 2000). Indigenous worldviews thus defy the distinction between people and nature (Flint et al. 2013) and speak instead to broader communities of life.

Local Indigenous food systems include the harvest of locally available, nondomesticated wildlife (i.e., plants and animals) for human consumption (Kuhnlein and Receveur 1996). Also referred to as traditional food, country food, or wild food systems, local Indigenous food systems are social-ecological systems defined by the use and stewardship of local biodiversity as a source of food (Olsson et al. 2004), embodying the knowledge, relationships, and reciprocities that connect people to nature and create the possibility of "being alive well" (Stevens 1997, Adelson 2000). Accordingly, local food systems are inextricably linked with the identity, food security, and well-being of Indigenous peoples (Kuhnlein et al. 2013), representing a cultural strength and a source of cultural identity (Kuhnlein et al. 2009). Language and food are interdependent components of Indigenous cultures (McIvor et al. 2013), and the remarkable diversity of Indigenous dialects, languages, and language families, coupled with their distinct and diversified local food systems, speaks to the collective richness, diversity, and relatedness of the world's many Indigenous peoples (Kuhnlein et al. 2013).

Most research on local Indigenous food systems focuses on health outcomes, environmental impacts, or cultural aspects. Healthrelated traditional food research focuses primarily on food-tohealth outcomes, emphasizing the unique nutrient profiles and high nutritional value of traditional foods (Kuhnlein and Receveur 2007, Johnson-Down and Egeland 2010, Egeland et al. 2011, Kenny et al. 2018b); their contributions to food security (Lambden et al. 2007, Power 2008, Kasimba et al. 2018) and reduced incidence of chronic health conditions, including diabetes and obesity (Young et al. 2000, Milburn 2004, Egeland et al. 2011, Marushka et al. 2017); and their role in food-borne contaminant and disease exposure (Kuhnlein and Chan 2000, Donaldson et al. 2010, Quinn et al. 2012, Dudley et al. 2015, Binnington et al. 2016). Environment-related traditional food research focuses primarily on environment-to-food impacts, emphasizing the climate vulnerability of traditional food systems (Krupnik and Jolly 2002, Furgal and Seguin 2006, Ford 2009, Royer 2015), including observed changes in the abundance and health of harvested species (Wassmann et al. 2011, Dinero 2013, Kenny et al. 2018a) and the increased difficulty and risk of 
Fig. 1. Indigenous communities or regional groups of communities included in the study (black circles) and their cultural (A) and ecological (B) affiliations. Community or region name abbreviations: $\mathrm{CH}=$ Chisasibi, $\mathrm{CL}=\mathrm{Colville}$ Lake, $\mathrm{EA}=\mathrm{Eastmain}, \mathrm{FC}=$ Fort Chipewyan, FGH = Fort Good Hope, FP = Fort Providence, FSe $=$ Fort Severn, FSm $=$ Fort Smith, HB = Hudson Bay (including Akulivik, Puvirnituq, Inukjuak, Umiujaq, Kuujjuarapik), HJ = Haines Junction, HS = Hudson Strait (including Ivujivik, Salluit, Kangiqsujuaq, Quaqtaq), KA = Kangiqsujuaq, KR = Kugaaruk, MI = Mistissini, OC = Old Crow, QI = Qikiqtarjuaq, SN = Sanikiluaq, TE = Teslin, UB = Ungava Bay (including Kangirsuk, Aupaluk, Tasiujaq, Kuujjuaq, Kangiqsualujjuaq), WA = Waswanipi, WE = Wemindji, WH = Whapmagoostui, $\mathrm{WK}=$ Waskaganish .
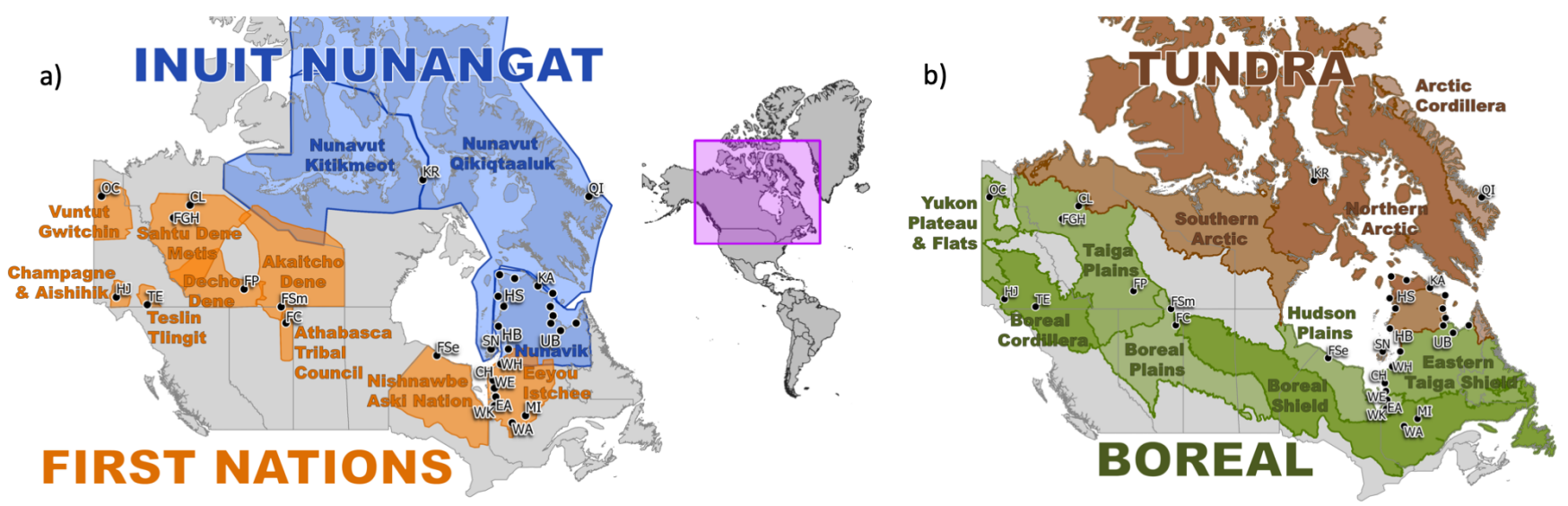

traveling to traditional harvest sites (Berkes and Jolly 2001, Ford et al. 2006, Laidler et al. 2009). Culture-related traditional food research considers culture-to-food and food-to-culture interdependencies more holistically, including traditional ecological knowledge as way of knowing (Adelson 2000, Berkes 2012), the importance of language and intergenerational knowledge transmission (Houde 2007, Parlee et al. 2014), the cultural practice of food choice and food sharing (Delormier et al. 2009, Collings et al. 2016, Ready 2018), and the evolution and interrelatedness of subsistence and wage economies (Wenzel 1991, Natcher 2009).

Local food use by Indigenous peoples is presumably both ecologically determined and culturally defined (Burlingame and Dernini 2012, Hickey et al. 2016), but evidence for this presumption arises largely from qualitative case studies (Liu et al. 2007, Kuhnlein et al. 2009). From an ecological perspective, food choice within a local food system is, by definition, constrained to locally available wildlife whose distributions are ecologically defined. The geographic range distributions of different wildlife species determines their local availability to communities (Wein and Freeman 1995). For instance, communities living on the coast have access to marine environments with a variety of plant and animal species that are not available to inland communities (Turner 1995, Mitchell and Donald 2001, Mulrennan and Bussières 2018). Similarly, communities located in mountainous regions will have access to a different complement of species than do those situated in lowland forests or grasslands (Turnbull 1987, Marean 1997, Arnold et al. 2011, Zimmerer et al. 2017). Communities situated at ecosystem edges are likely to have access to the widest diversity of assemblages (Turner et al. 2003). However, these environmental determinants of food availability and accessibility may not be the only, or necessarily the most important, determinant of Indigenous peoples' food use (Wein et al. 1996). Food choice and food use are widely recognized as a social and cultural phenomenon that are closely related to identity (Fischler 1988). Food and eating is fundamentally a social practice (Delormier et al. 2009). For Indigenous peoples, harvesting food from the wild is deeply connected with spirituality, ways of seeing life, language, and links to ancestors and thus forms the base of their ethics and identity (Kuhnlein et al. 2009). As such, different Indigenous cultures have distinct knowledge, practices, preferences, and taboos surrounding the same animal (Kuhnlein and Humphries 2017).

Food and feeding are largely cultural. Biodiversity is largely ecological. When local biodiversity is used as food, is the local food system culturally or ecologically defined? We capitalize on and combine three key analytical opportunities to address this question. The first is that local food use by Indigenous communities has been relatively well quantified, particularly in northern North America, through food frequency and food recall questionnaires, typically employed by public health researchers seeking to estimate contaminant exposure or nutrient intake (Thompson and Subar 2017). The second is the recognition that these surveys yield data directly amenable to dietary niche metrics that have long been used in the ecological sciences to assess trophic specialization and niche overlap (Colwell and Futuyma 1971). The third is the availability of variance partitioning statistical approaches capable of quantifying shared and independent explanatory power and thus communicating the unique and shared contributions of nature and culture in social-ecological systems. Here, we characterize cultural and ecological contributors to the local food use of 21 Indigenous communities distributed across northern North America, whose patterns of local food use have been systematically surveyed and published in the public domain, including 7 Inuit communities or regions and 14 First Nations communities (Fig. 1). Linguistic analysis of Indigenous languages spoken in North America is used as a basis for characterizing the cultural relatedness of these communities 
(Fig. A1.1; Mithun 2001), which are also situated in distinct ecological landscapes predictive of the species assemblies of locally available wildlife (Fig. 1B; McDonald et al. 2005, Soininen et al. 2007). We describe the dietary importance of different wild animal species across the range of communities included and assess the extent to which dietary diversity correlates with geography, culture, and ecology. The analysis thus characterizes the biocultural diversity of local food use and assesses the relative importance of environmental and cultural determinism. By showing how trophic niche metrics, used widely in ecology, can be applied to the results of traditional food surveys, we hope to encourage integration of ecological, health, and cultural approaches to describe the social-ecology of local Indigenous food systems.

\section{METHODS}

\section{Indigenous communities and food frequency questionnaires}

The published literature was searched for studies that describe the local wild animal food consumption patterns of Indigenous communities in Canada. The authors of those studies interviewed community members using food frequency or dietary recall questionnaires, asking participants how often (e.g., number of days per month) or how much of (e.g., mass per day) various animals were consumed. Although wild plant foods are also critically important to Indigenous peoples as food and medicine (Kuhnlein and Turner 1991, Grivetti and Ogle 2000), plant-based contributions to local food systems were excluded from our analysis, not because their contributions were unimportant or undocumented, but because plant-based portions of most food frequency surveys conducted in northern Canada do not include recognizable species categories (e.g., reported consumption of berries without identification of species). We restricted our analysis to studies that reported food consumption patterns per community or across a series of neighboring communities. When a community appeared in more than one study, the data set that was the most taxonomically detailed or seasonally comprehensive was selected. Most studies included in our analysis reported animal food consumption patterns for a complete year, but a few studies focusing on specific seasons were included, despite potential differences between seasonal and annual consumption. We identified 12 published studies that satisfied the above criteria, representing 32 communities located across northern Canada. Because three studies pooled data across a few neighboring communities, our analysis considered 21 communities or community groups (Table A1.1 in Appendix 1).

\section{Dietary data analysis}

Combining surveys from multiple communities required standardization of wildlife categories at the species or speciesgroup level and converting the heterogeneity of surveyed variables (e.g., days with consumption, number of meals per day, grams consumed per day) into within-study importance values. Thus, our analysis does not consider community-to-community variation in the amount of local wildlife food consumed, but rather, how the total amount of local consumption is distributed across various wildlife species and species-groups. In equation form,

$$
\sum_{i=m}^{n} p_{i}=1
$$

where $n$ is the number of species (or species-groups) consumed and $p_{\mathrm{i}}$ represents the proportion of reported food consumption for species $i$. This cross-study standardization generates a matrix of community-by-species dietary importance values (Fig. 2; Table A1.2 in Appendix 1).

Using this standardized dietary importance matrix, we performed nonmetric multidimensional scaling (NMDS), an ordination technique based on ranked orders, to visualize and interpret the position of communities in the multidimensional space of species consumed. In the R package "vegan" (Oksanen et al. 2018, R Core Team 2019), we used the Jaccard ordination distance because it is an ecologically meaningful measure based on the dissimilarity of resources used among communities (Jaccard 1901, McCune et al. 2002). Twenty dimensions were run to find the solution with minimized stress (stress $=0.03$ ) and to obtain the best visualization of the position of communities along two axes of variation in species importance. Then, using the $\mathrm{R}$ package "RInSp" (Zaccarelli et al. 2013, R Core Team 2019), we calculated the trophic niche breadth of each community (a measure of diet specialization ranging from 0 , when most specialized, to 1 , when most generalized) and the trophic niche overlap between each community pair (pairwise measure of diet similarity ranging from 0 , when a community pair consumes no common species, to 1 , when a community pair consumes the same species in identical proportions; hereafter referred to as pairwise dietary similarity).

\section{Correlates of diet similarity}

We related pairwise dietary similarity to metrics of cultural and ecological relatedness. Our pairwise measure of cultural relatedness is language based, reflecting the cultural dendrogram presented in Fig. 2, ranging from a maximum value of 4 for community pairs sharing a cultural group, language family, and language (e.g., multiple Cree communities in Eeyou Istchee), to a minimum value of 1 for community pairs belonging to distinct cultural groups (e.g., Inuit and First Nations) and, therefore, distinct language families and languages. An alternative index of cultural relatedness was also considered, assigning a relatedness measure ranging from 1 to 10 based on more detailed subcategories of cultural and linguistic groups (Fig. A1.1 in Appendix 1). Both of these cultural metrics are dependent on accurate linguistic classification of Indigenous language families, as well as the validity of assessing cultural relatedness on the basis of language diversity, both of which are complex and contested ideas (Bateman et al. 1990, Bryant et al. 2005). Similar to the metric of cultural relatedness, ecological relatedness was calculated for each community pair, with the highest value (3) assigned to community pairs sharing a biome and ecoregion, and the lowest value (1) assigned to community pairs differing in biomes. An alternative index of ecological relatedness, consisting of four levels, included additional information related to coastal proximity and ecozone adjacency (Fig. A1.1 in Appendix 1). Finally, we also calculated the geodesic distance between community pairs to generate a distance-based predictor variable that is entirely spatial and thus culturally and ecologically neutral. This spatial distance metric was measured along the surface of the earth, estimated using the central latitude and longitude coordinates of each community. The pairwise community matrices of cultural relatedness, ecological relatedness, and spatial distance used in these analyses are included in Appendix 1, Table A1.3. 
Fig. 2. Community-by-species standardized dietary importance matrix based on local food use surveyed in 21 Indigenous communities or regional groups of communities. Wildlife species and species groups are connected by a dendrogram reflecting taxonomic groupings. Communities are connected by a dendrogram reflecting cultural and linguistic relatedness, with communities separated at the base of the dendrogram (where community names are listed) having fewer similarities than those separated higher up. First Nation (FN) connections reflect the Na-Dene (ND) language family, which includes Tlingit (Teslin) and the Athabaskan languages Tutchone (Haines Junction), Gwitchin (Old Crow), and Dene (three branches beginning with Fort), and the Algonquian language family (A), which includes Swampy Cree (SC) and Eastern Cree (EC). Inuit (I) connections reflect culturally and linguistically defined regions, including Nunavik (N) and the Kitikmeot (K) and Qikiqtaaluk (Q) regions of Nunavut.

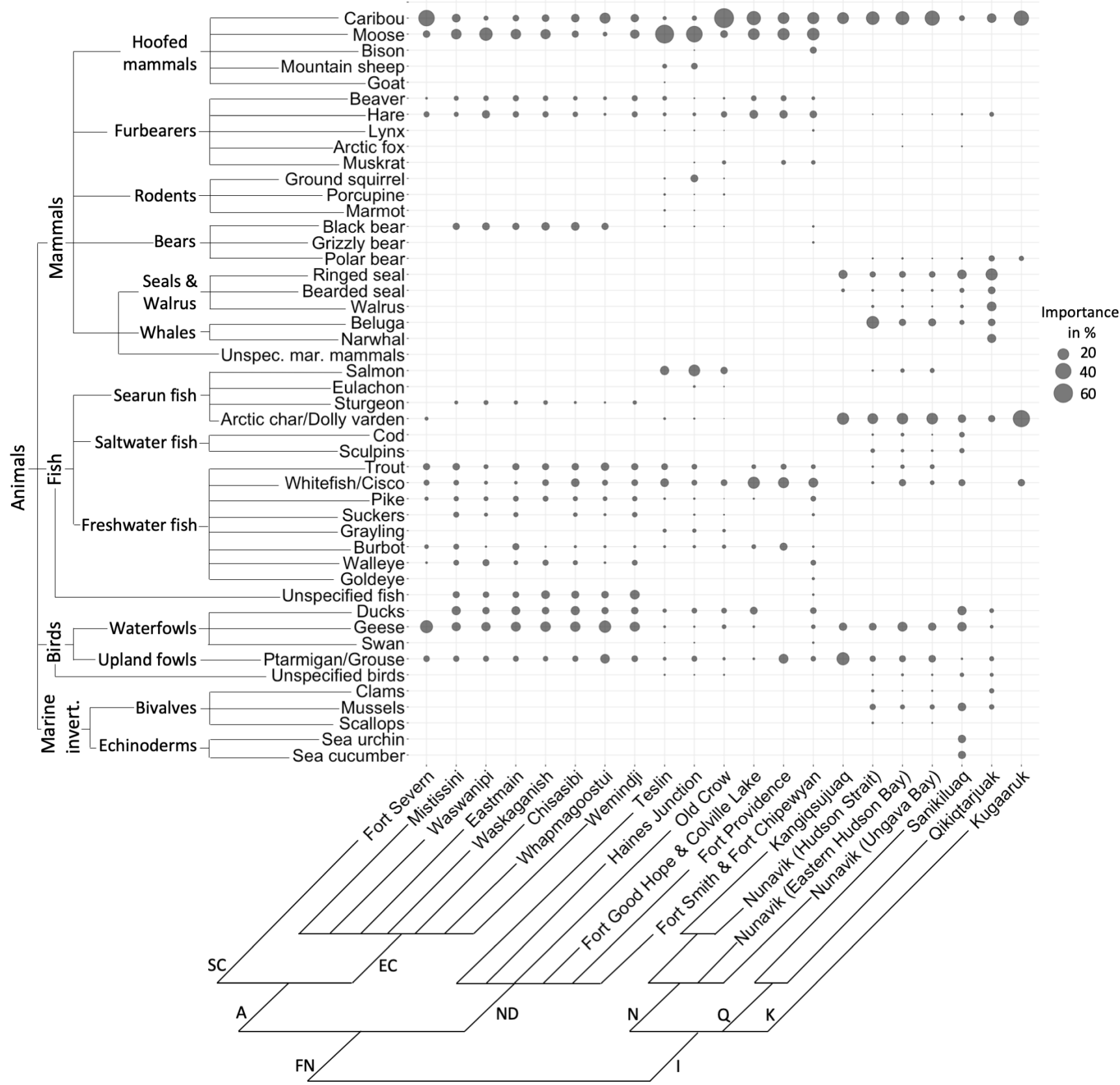


Assessing the relative contributions of culture, ecology, and space in defining the types and amounts of species consumed as local food is made challenging by the covariation in culture and ecology that defines social-ecological and biocultural systems. Accordingly, we assessed the explanatory power of cultural relatedness, ecological relatedness, and spatial distance in relation to diet similarity using multiple approaches, including univariate correlations, model selection using the Akaike Information Criterion (AIC), and variance partitioning, all performed using $\mathrm{R}$ (R Core Team 2019). Because pairwise comparisons generate pseudoreplication (i.e., data from 21 communities or community groups yield 210 comparisons), and because two of our three explanatory variables are discrete, we confine our univariate analyses to a comparison of $R^{2}$ coefficients of determination, used and interpreted here as an initial assessment of explanatory power with no estimation or reporting of statistical significance due to pseudoreplication. We then used a standard AIC model selection framework to compare seven candidate models containing combined and single cultural, ecological, and spatial predictors of dietary similarity. Finally, a variance partitioning analysis (Borcard et al. 1992), also referred to as dominance analysis (Budescu 1993) or independent effects analysis (Murray and Conner 2009), was used as an alternative statistical approach that seeks to partition the shared vs. independent explanatory power of a series of partially correlated predictor variables. We follow the convention of presenting the outcome of a variance partitioning analysis as a Venn diagram, with overlapping circles reflecting predictive power of one explanatory variable that is shared with other explanatory variables.

\section{RESULTS}

Across the 21 Indigenous communities or regional groups of communities that were surveyed, most consumed $>10$ different animal species or species-groups and, over all communities, 45 species-groups or animals were consumed (Fig. 2). Caribou was the most widely consumed animal food species, followed by geese (including Canada Goose, Snow Goose, etc.), moose, whitefish/ cisco, and grouse/ptarmigan. A measure of trophic niche breadth, reflecting both the diversity and evenness of species-groups consumed, declined significantly with latitude $\left(R^{2}=0.45\right.$; Fig. $3 \mathrm{~A})$, and increased significantly with average annual temperature $\left(R^{2}=0.40\right.$; Fig. 3B).

Multivariate (NMDS) analysis of community-by-species dietary importance values positioned communities in species space along two multivariate axes reflecting rank order variation in species consumed (Fig. 4). The first axis of the NMDS differentiated communities reporting diets dominated by marine and marineassociated species such as arctic char, seals, and beluga from those consuming more terrestrial and freshwater-associated species such as moose, trout, and beaver (Fig. 4; Fig. A1.2 in Appendix 1). This axis reflects a widely recognized distinction between the country food systems of Inuit communities, focused on coastal and marine species, and the traditional food systems of First Nation communities, focused on terrestrial and freshwater species. The central location of caribou and geese along this first axis reflects the shared importance of these migratory species to Inuit and First Nations. The second NMDS axis highlighted a less discussed, largely east-to-west, difference in local food use, including central Inuit communities consuming more caribou and char relative to eastern Inuit communities consuming more seal and marine invertebrates, as well as northwestern First Nations communities consuming more caribou, moose, porcupine, and whitefish/cisco relative to northeastern First Nations communities consuming more waterfowl, bears, beaver, and freshwater fish such as walleye and pike (on the terrestrial side of the first axis; Fig. 4; Fig. A1.2 in Appendix 1).

Fig. 3. Trophic niche breadth of 21 Indigenous communities or regional groups of communities based on surveyed local food use in relation to latitude (A) and average annual temperature (B). Niche breadth is a measure of diet specialization ranging from 0 , when diet is most specialized, to 1 , when diet is most generalized. The shaded area represents the $95 \%$ confidence interval.

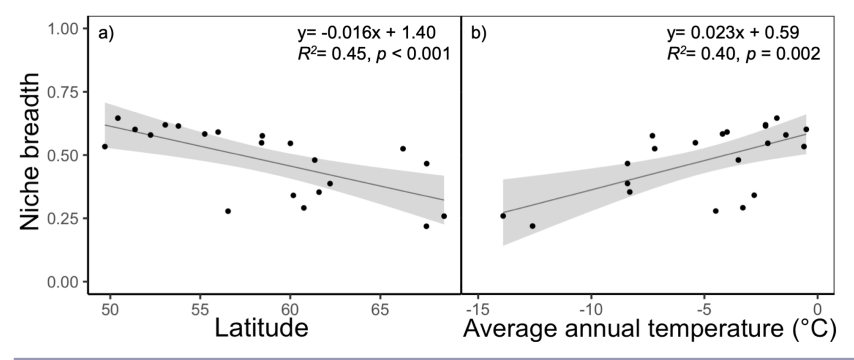

Univariate analysis of cultural relatedness, ecological relatedness, and spatial distance as predictors of dietary similarity highlights the predictive capacity of all three variables (Fig. 5). However, these three predictor variables are moderately collinear, with similar cultures characterized by ecological similarity $(r=0.64)$ and spatial proximity ( $r=0.40 ;$ Fig. 5$)$. Variance inflation factors for cultural relatedness (2.05), ecological relatedness (1.75), and spatial distance (1.24) confirmed that collinearity is low enough to include variables in a combined linear model. Application of a standard AIC model comparison framework to this moderately correlated set of predictor variables indicates maximum support for a combined model that includes cultural, ecological, and spatial predictors of dietary similarity (Table 1).

Variance partitioning analysis of culture, ecology, and space as predictors of dietary similarity indicates a persuasive influence of culture on diet, with cultural relatedness offering $66 \%$ predictive power, which is only $4 \%$ less than the $70 \%$ contributed by all three variables combined (Fig. 6). Approximately one-third of the predictive power of cultural relatedness is contributed by cultural relatedness that is uncorrelated with other predictors $(21 \%)$, slightly more than one-third is contributed by cultural relatedness that is correlated with ecological relatedness $(25 \%)$, and lesser amounts are contributed by culture correlated with spatial distance $(14 \%)$ and all three variables correlated together $(6 \%)$. The independent explanatory power of cultural relatedness $(21 \%)$ is 7 times greater than the independent explanatory power of spatial distance $(3 \%)$ and 21 times greater than that of ecological relatedness $(1 \%)$. This identified importance of culture in predicting dietary similarity was robust to alternative measures of cultural and ecological relatedness (Fig. A1.3 in Appendix 1).

\section{DISCUSSION}

Reliance on local biodiversity as a primary source of food connects nature to the well-being of people in a direct and 
Fig. 4. Ordination biplot for nonmetric multidimensional scaling analysis of a community-byspecies standardized dietary importance matrix based on local food use surveyed in 21 Indigenous communities or regional groups of communities. Communities are shown as dots coloured by culture and are positioned along two multivariate axes of variation in the dietary importance of species consumed, with closer dots having more similar diets. Community or region name abbreviations: $\mathrm{CH}=$ Chisasibi, $\mathrm{EA}=$ Eastmain, $\mathrm{FGH} / \mathrm{CL}=$ Fort Good Hope and Colville Lake, $\mathrm{FP}=$ Fort Providence, $\mathrm{FSe}=$ Fort Severn, FSm/FC = Fort Smith and Fort Chipewyan, $\mathrm{HB}=$ Hudson Bay (including Akulivik, Puvirnituq, Inukjuak, Umiujaq, Kuujjuarapik), HJ = Haines Junction, HS = Hudson Strait (including Ivujivik, Salluit, Kangiqsujuaq, Quaqtaq), KA = Kangiqsujuaq, KR = Kugaaruk, MI = Mistissini, OC = Old Crow, QI = Qikiqtarjuaq, SN = Sanikiluaq, TE = Teslin, UB = Ungava Bay (including Kangirsuk, Aupaluk, Tasiujaq, Kuujjuaq, Kangiqsualujjuaq), WA = Waswanipi, WE $=$ Wemindji, $\mathrm{WH}=$ Whapmagoostui, $\mathrm{WK}=$ Waskaganish. Species that were most important in driving variation along each NMDS axis are indicated with crosses, and species illustrations and are positioned according to how the dietary importance of each species is correlated with each NMDS axis (see Fig. A1.2 in Appendix 1 for a visualization with all species). Cultural-linguistic groupings are highlighted with dashed ellipses for First Nations (orange) and Inuit (blue) and with solid ellipses for Nunavut, Nunavik, Cree/ Algonquian, and Na-Dene/Athabaskan.
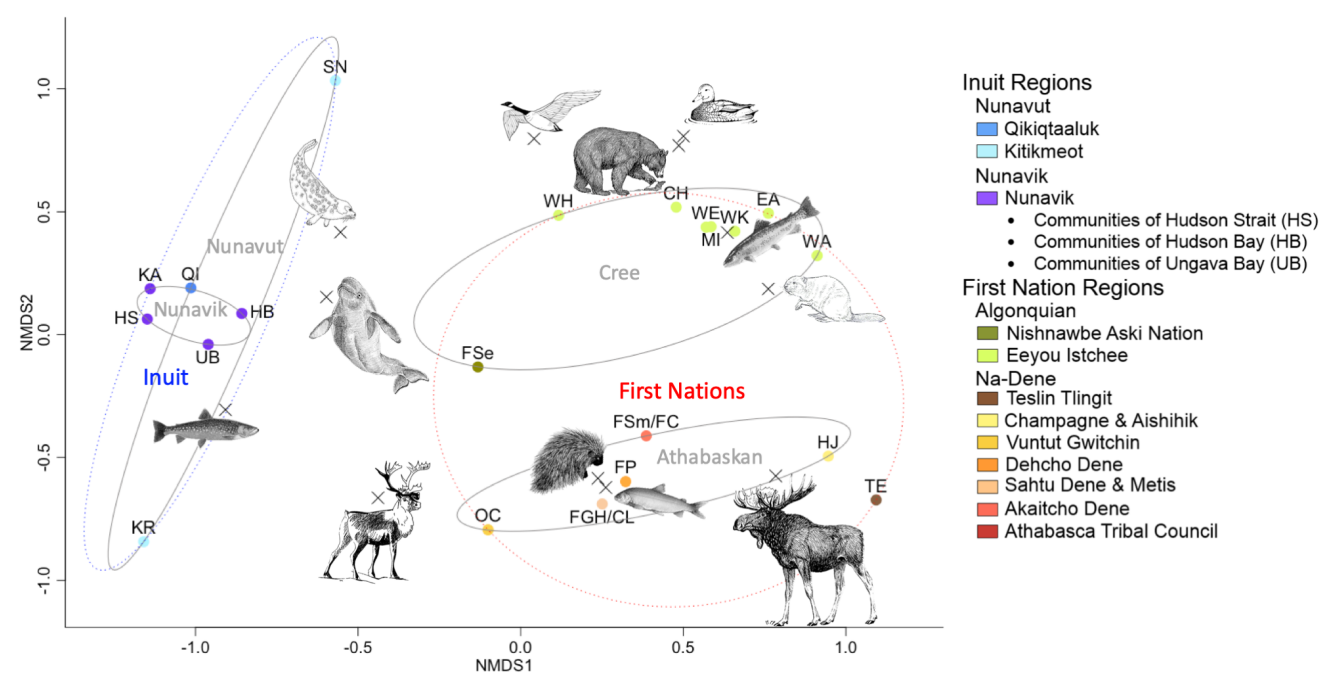

fundamental way. When this food-based connection to nature is developed and sustained generation after generation from time immemorial, as is the case for Indigenous peoples throughout the world, then knowledge and tradition both arise from and maintain the continuity of this food-based relationship (Kuhnlein et al. 2009). Culture, ecology, and place become integrated to an extent that their independent and combined influences become difficult to identify (Berkes 2012). We achieve this description quantitatively with a standardized analysis of local food use by Indigenous communities across northern North America, using language families to reflect cultural relatedness, biomes and ecozones to reflect ecological relatedness, and a distance-based measure of spatial proximity.

That this analysis reveals such a profound and prevailing importance of culture in defining food use is surprising because ecological niche-based metrics form the basis of our analytical approach and because food choice within a local food system is, by definition, constrained to locally available wildlife whose distributions are presumably ecologically defined. The importance of culture in shaping local food consumption could arise from preferential use and selection of preferred species within a diverse community of locally available wildlife, meaning that local diets reflect food preference more than availability or access. Alternatively, culturally preferred species may be more readily available and accessible to local communities if harvest increases local availability or if the details of how and where people hunt dictate the species that are accessible to them. In all cases, for culture to shape food use in a long-term biocultural relationship, harvest must be sustainable, and the cultural preferences and traditions of harvesters and food consumers must be of fundamental importance. Although our results highlight the importance of culture in patterns of food consumption, so too do they align with the fundamental environmental constraint that local diets are limited to local wildlife assemblages. If we were to compare community reported consumption of individual species to these species' range distributions, we believe that all species reported to be consumed would be confirmed to be locally present. Consistent with large-scale biodiversity gradients reported in macro-ecological literature (Gaston 2000), communities located at higher latitudes and colder climatic zones had less diverse, more specialized diets (i.e., narrower trophic 
Fig. 5. Pairwise diet similarity based on local food use surveyed among 21 Indigenous communities or regional groups of communities, in relation to cultural relatedness (A), spatial distance (B), and ecological relatedness (C) between communities. Dashed lines and coefficients of correlation $(r)$ indicate collinearity between explanatory variables. Diet similarity ranges from 0 , when a community pair consumes no common species, to 1 , when a community pair consumes the same species in identical proportions. Cultural relatedness is highest (4) for community pairs sharing a cultural group, language family, and language, and lowest (1) for community pairs belonging to distinct cultural groups and, therefore, distinct language families and languages. Ecological relatedness is highest (3) for community pairs sharing biome and ecoregion and lowest (1) when community pairs are in different in biomes and, thus, in different ecoregions.

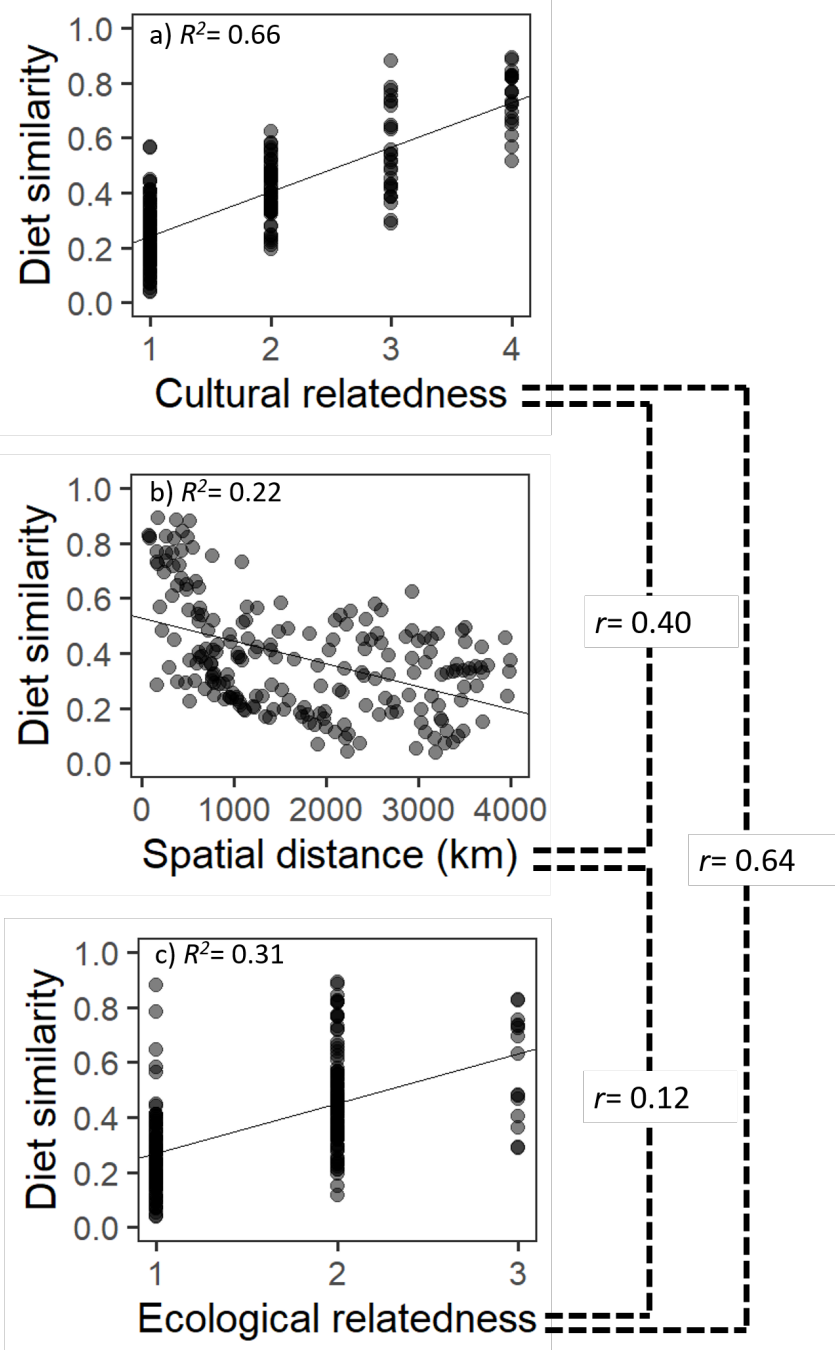

niches) than communities located at lower, warmer latitudes. Season-to-season and year-to-year variation in wildlife abundance and accessibility is also likely to be a key driver of local diets. The absence (or inconsistency of) longitudinal data in
Table 1. Model selection from seven candidate linear models containing combined and single cultural, ecological, and spatial predictors of pairwise dietary similarity among 21 Indigenous communities or regional groups of communities. The Akaike Information Criterion (AIC) shows the relative strengths of the models, with lower AIC indicating a stronger model. AIC scores $(\triangle \mathrm{AIC})$ represent the relative difference between the best model and each other model. Akaike weights $\left(\mathrm{W}_{\mathrm{i}}\right)$ give the probability that any given model is the best of the set.

\begin{tabular}{lccc}
\hline \hline Candidate models & AIC & $\Delta$ AIC & $\mathrm{W}_{\mathrm{i}}$ \\
\hline CULTURAL + ECOLOGICAL + & 1611.26 & 0 & 0.809 \\
SPATIAL & & & \\
CULTURAL + SPATIAL & 1614.15 & 2.89 & 0.191 \\
CULTURAL & 1629.1 & 17.84 & 0 \\
CULTURAL + ECOLOGICAL & 1629.4 & 18.14 & 0 \\
SPATIAL + ECOLOGICAL & 1722.54 & 111.28 & 0 \\
ECOLOGICAL & 1779.59 & 168.33 & 0 \\
SPATIAL & 1804.92 & 193.66 & 0 \\
\hline
\end{tabular}

Fig. 6. Venn diagram showing variance partitioning and shared and unique explanatory power of cultural, ecological, and spatial predictors of pairwise community diet similarity.

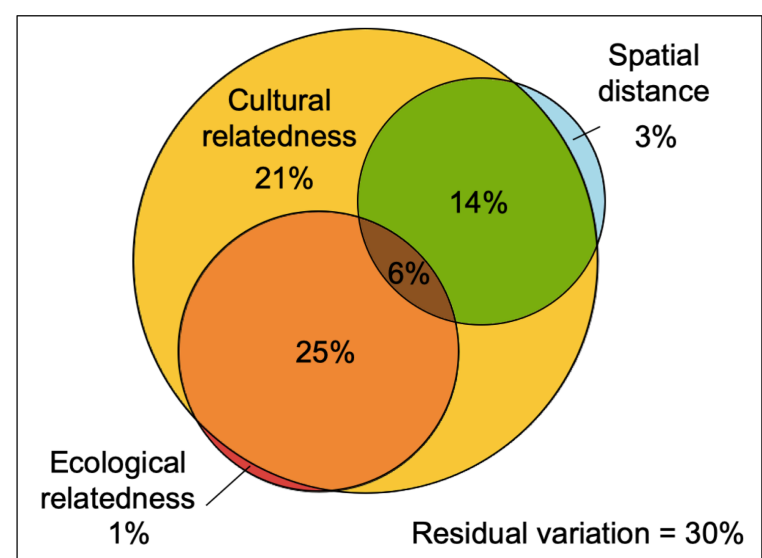

the surveys we analyzed precluded examination of seasonal or multiannual variation in consumption patterns, which are known to be substantial and driven by both environmental conditions and social factors. Furthermore, food frequency questionnaires and dietary recall surveys, which form the foundation of our analyses, are known to be imperfect instruments of dietary assessment because of recall inaccuracies, reporting bias, and the difficulty of estimating amounts from frequencies (Castell et al. 2015, Thompson and Subar 2017). However, some of these sources of variation, error, and bias were likely reduced or eliminated by our conversion of raw data into within-study importance values, and those that remained should have contributed primarily unexplained variation. One potential bias that could inflate diet-culture coupling is the possibility that communities over-report the consumption of species that are cultural cornerstones and under-report other locally available wildlife that are consumed but are less culturally emphasized. 
The results described here also relate to the important issue of community adaptive capacity in an era of rapid environmental change (Harper et al. 2019). The expectation that community harvest practices and food use will simply change as local ecological conditions change rests on environmental determinism independent of cultural factors (Robertson and Ljubicic 2019), which is equivalent to the small red space labeled as ecological relatedness in our variance partitioning analysis (Fig. 6). The smallness of this predictive space (representing diet predicted by ecology independent of culture and spatial distance) should give pause to this expectation; it ignores the extensive overlap among cultural, ecological, and spatial circles reflecting social-ecological coupling and biocultural relationships. The tensions and stresses created by environmental change can be envisioned as what happens when the ecological circle is moved away from the other two (Fig. 6). For example, the thin red space might, if diets become more environmentally determined, expand into a larger space. For this expansion to occur, however, social-ecological coupling must decline. Whatever the response or adaptation, environmental change will cause a pulling apart of people, environment, and place. Nevertheless, all long-term relationships change over time, and the relationship between Indigenous peoples and nature is a long-term relationship (Kuhnlein et al. 2009). The contemporary social-ecological system we document here is inevitably a product of many past episodes of cultural and environmental change, sometimes occurring in parallel and at other times with one far outpacing the other. Thus, continuity of social-ecological change is a reasonable expectation, so long as it is realized the change will be shaped by people and nature combined.

Local food systems are critically important to the health and culture of the world's Indigenous peoples, many of whom are experiencing a global syndemic of obesity, undernutrition, and climate change (Swinburn et al. 2019). Local food systems are also important to the global biodiversity crisis as either drivers of biodiversity loss (Fa et al. 2002) or contributors to biodiversity protection (Gadgil et al. 1993), depending on system properties (Berkes and Folke 2000). Because most Indigenous food systems research focuses on impacts and outcomes, there is a risk of overlooking the food system itself. The material basis of local food systems is the diversity of wild organisms that are consumed as food, their species identities, and their ecological niches (Kuhnlein and Humphries 2017). The cultural basis of local food use includes not only the traditional ecological knowledge of wildlife species and the methods and equipment required to harvest them, but also issues of taste, preference, identity, and spirituality (Berkes 2012), all of which come to define food sufficiency, nutrient adequacy, cultural acceptability, safety, certainty, and stability (Coates 2013). Documenting contemporary local food systems impacts and outcomes and predicting those that will occur in the future requires a detailed and comprehensive understanding of ecological and cultural determinants of local food use and how these determinants coalesce as a social ecological system. We hope that our application of trophic niche metrics from the ecological sciences to the results of traditional food surveys will encourage integration of ecological, health, and cultural approaches to describe the social-ecology of local Indigenous food systems, including how these systems vary from place to place and from one time to another.

\section{CONCLUSION}

Understanding the relationship between people and the environment is a challenge as old as humanity that has become the defining problem of the Anthropocene. Here, we used ecological niche metrics to analyze patterns in the local food use of Indigenous peoples. Food and feeding are largely cultural. Biodiversity is largely ecological. When local biodiversity is used as food, is the local food system culturally or ecologically defined? Our analyses confirm what can be most difficult to quantify: the importance of culture in defining how people use and benefit from nature, operating within the environmental constraints defining local availability. These results reveal the sustainability and cultural agency inherent in local food systems, and the importance of cultural-ecological coupling in an era of accelerating social and environmental change.

Responses to this article can be read online at: http://www.ecologyandsociety.org/issues/responses. php/11542

\begin{abstract}
Acknowledgments:
The authors acknowledge the Indigenous communities and community-based researchers whose experience, expertise, and participation made this meta-analysis possible. Dr. Elizabeth Robinson identified the analytical opportunity. Gordon Hickey and Treena Delormier provided insightful comments related to the context, analyses, and interpretation. Funding was received from the Institut Nordique du Québec McGill Chair in Northern Research and the Natural Sciences and Engineering Research Council of Canada's Discovery Grant and Northern Supplement Program. Authors RT, ML-C, and MMH collectively conceived the study and the analytical approach; $R T$ and $M L-C$ led the acquisition and analysis of data; and $R T, M L-C$, and $M M H$ collectively interpreted the data and together drafted the manuscript.
\end{abstract}

\section{Data Availability Statement:}

All data are available in the main text of the manuscript or in the appendix.

\section{LITERATURE CITED}

Adelson, N. 2000. 'Being alive well': health and the politics of Cree well-being. University of Toronto Press, Toronto, Canada.

Arnold, M., B. Powell, P. Shanley, and T. C. H. Sunderland. 2011. Forests, biodiversity and food security. International Forestry Review 13(3):259-264. https://doi.org/10.1505/146554811798293962

Bateman, R., I. Goddard, R. O’Grady, V. A. Funk, R. Mooi, W. J. Kress, P. Cannell, D. F. Armstrong, D. Bayard, B. G. Blount, C. A. Callaghan, L. L. Cavalli-Sforza, A. Piazza, P. Menozzi, J. Mountain, J. H. Greenberg, K. Jacobs, Y. Mizoguchi, M. Nunez, and R. L. Oswalt. 1990. Speaking of forked tongues: the feasibility of reconciling human phylogeny and the history of language [and comments]. Current Anthropology 31(1):1-24. https://doi. org/10.1086/203800 
Berkes, F. 2012. Sacred ecology. Third edition. Routledge, New York, New York, USA.

Berkes, F., and C. Folke, editors. 2000. Linking social and ecological systems: management practices and social mechanisms for building resilience. Cambridge University Press, Cambridge, UK.

Berkes, F., and D. Jolly. 2001. Adapting to climate change: socialecological resilience in a Canadian western Arctic community. Conservation Ecology 5(2):18. https://doi.org/10.5751/ES-00342-050218

Binnington, M. J., M. S. Curren, H. M. Chan, and F. Wania. 2016. Balancing the benefits and costs of traditional food substitution by indigenous Arctic women of childbearing age: impacts on persistent organic pollutant, mercury, and nutrient intakes. Environment International 94:554-566. https://doi.org/10.1016/j. envint.2016.06.016

Borcard, D., P. Legendre, and P. Drapeau. 1992. Partialling out the spatial component of ecological variation. Ecology 73 (3):1045-1055. https://doi.org/10.2307/1940179

Bryant, D., F. Filimon, and R. D. Gray. 2005. Untangling our past: languages, trees, splits and networks. In R. Mace, C. J. Holden, and S. Shennan, editors. The evolution of cultural diversity: a phylogenetic approach. Left Coast Press, Walnut Creek, California, USA.

Budescu, D. V. 1993. Dominance analysis: a new approach to the problem of relative importance of predictors in multiple regression. Psychological Bulletin 114(3):542-551. https://doi. org/10.1037/0033-2909.114.3.542

Burlingame, B., and S. Dernini, editors. 2012. Sustainable diets and biodiversity: directions and solutions for policy, research and action. Proceedings of the international scientific symposium Biodiversity and Sustainable Diets United Against Hunger. Food and Agriculture Organization, Rome, Italy. [online] URL: http:// www.fao.org/3/i3004e/i3004e00.htm

Castell, G. S., L. Serra-Majem, and L. Ribas-Barba. 2015. What and how much do we eat?24-hour dietary recall method. Nutrición Hospitalaria 31(S3):46-48. [online] URL: http://www.nutricionhospitalaria. com/pdf/8750.pdf

Coates, J. 2013. Build it back better: deconstructing food security for improved measurement and action. Global Food Security 2 (3):188-194. https://doi.org/10.1016/j.gfs.2013.05.002

Collings, P., M. G. Marten, T. Pearce, and A. G. Young. 2016. Country food sharing networks, household structure, and implications for understanding food insecurity in Arctic Canada. Ecology of Food and Nutrition 55(1):30-49. https://doi. org/10.1080/03670244.2015.1072812

Colwell, R. K., and D. J. Futuyma. 1971. On the measurement of niche breadth and overlap. Ecology 52(4):567-576. https://doi. org/10.2307/1934144

Delormier, T., K. L. Frohlich, and L. Potvin. 2009. Food and eating as social practice - understanding eating patterns as social phenomena and implications for public health. Sociology of Health and Illness 31(2):215-228. https://doi.org/10.1111/ j.1467-9566.2008.01128.x
Díaz, S., S. Demissew, J. Carabias, C. Joly, M. Lonsdale, N. Ash, A. Larigauderie, J. R. Adhikari, S. Arico, A. Báldi, A. Bartuska, I. A. Baste, A. Bilgin, E. Brondizio, K. M. A. Chan, V. E. Figueroa, A. Duraiappah, M. Fischer, R. Hill, T. Koetz, P. Leadley, P. Lyver, G. M. Mace, B. Martin-Lopez, M. Okumura, D. Pacheco, U. Pascual, E. S. Pérez, B. Reyers, E. Roth, O. Saito, R. J. Scholes, N. Sharma, H. Tallis, R. Thaman, R. Watson, T. Yahara, Z. A. Hamid, C. Akosim, Y. Al-Hafedh, R. Allahverdiyev, E. Amankwah, S. T. Asah, Z. Asfaw, G. Bartus, L. A. Brooks, J. Caillaux, G. Dalle, D. Darnaedi, A. Driver, G. Erpul, P. EscobarEyzaguirre, P. Failler, A. M. M. Fouda, B. Fu, H. Gundimeda, S. Hashimoto, F. Homer, S. Lavorel, G. Lichtenstein, W. A. Mala, W. Mandivenyi, P. Matczak, C. Mbizvo, M. Mehrdadi, J. P. Metzger, J. B. Mikissa, H. Moller, H. A. Mooney, P. Mumby, H. Nagendra, C. Nesshover, A. A. Oteng-Yeboah, G. Pataki, M. Roué, J. Rubis, M. Schultz, P. Smith, R. Sumaila, K. Takeuchi, S. Thomas, M. Verma, Y. Yeo-Chang, and D. Zlatanova. 2015. The IPBES conceptual framework - connecting nature and people. Current Opinion in Environmental Sustainability 14:1-16. https:// doi.org/10.1016/j.cosust.2014.11.002

Dinero, S. C. 2013. Indigenous perspectives of climate change and its effects upon subsistence activities in the Arctic: the case of the Nets'aii Gwich'in. GeoJournal 78:117-137. https://doi.org/10.1007/ $\underline{\text { s10708-011-9424-8 }}$

Donaldson, S. G., J. Van Oostdam, C. Tikhonov, M. Feeley, B. Armstrong, P. Ayotte, O. Boucher, W. Bowers, L. Chan, F. Dallaire, É. Dewailly, J. Edwards, G. M. Egeland, J. Fontaine, C. Furgal, T. Leech, E. Loring, G. Muckle, T. Nancarrow, D. Pereg, P. Plusquellec, M. Potyrala, O. Receveur, and R. G. Shearer. 2010. Environmental contaminants and human health in the Canadian Arctic. Science of the Total Environment 408(22):5165-5234. https://doi.org/10.1016/j.scitotenv.2010.04.059

Dudley, J. P., E. P. Hoberg, E. J. Jenkins, and A. J. Parkinson. 2015. Climate change in the North American Arctic: a one health perspective. EcoHealth 12:713-725. https://doi.org/10.1007/ s10393-015-1036-1

Egeland, G. M., L. Johnson-Down, Z. R. Cao, N. Sheikh, and H. Weiler. 2011. Food insecurity and nutrition transition combine to affect nutrient intakes in Canadian Arctic communities. Journal of Nutrition 141(9):1746-1753. https://doi.org/10.3945/jn.111.139006

Ekins, P., S. Simon, L. Deutsch, C. Folke, and R. De Groot. 2003. A framework for the practical application of the concepts of critical natural capital and strong sustainability. Ecological Economics 44(2-3):165-185. https://doi.org/10.1016/S0921-8009 (02)00272-0

Fa, J. E., C. A. Peres, and J. Meeuwig. 2002. Bushmeat exploitation in tropical forests: an intercontinental comparison. Conservation Biology 16(1):232-237. https://doi.org/10.1046/j.1523-1739.2002.00275. $\underline{x}$

Fischler, C. 1988. Food, self and identity. Information (International Social Science Council) 27(2):275-292. https://doi. org/10.1177/053901888027002005

Flint, C. G., I. Kunze, A. Muhar, Y. Yoshida, and M. Penker. 2013. Exploring empirical typologies of human-nature relationships and linkages to the ecosystem services concept. Landscape and Urban Planning 120:208-217. https://doi. org/10.1016/j.landurbplan.2013.09.002 
Ford, J. D. 2009. Vulnerability of Inuit food systems to food insecurity as a consequence of climate change: a case study from Igloolik, Nunavut. Regional Environmental Change 9:83-100. https://doi.org/10.1007/s10113-008-0060-x

Ford, J. D., B. Smit, and J. Wandel. 2006. Vulnerability to climate change in the Arctic: a case study from Arctic Bay, Canada. Global Environmental Change 16(2):145-160. https://doi.org/10.1016/j. gloenvcha.2005.11.007

Furgal, C., and J. Seguin. 2006. Climate change, health, and vulnerability in Canadian northern Aboriginal communities. Environmental Health Perspectives 114:12. https://doi.org/10.1289/ ehp. 8433

Gadgil, M., F. Berkes, and C. Folke. 1993. Indigenous knowledge for biodiversity conservation. Ambio 22(2-3):151-156. [online] URL: https://www.jstor.org/stable/4314060

Gaston, K. J. 2000. Global patterns in biodiversity. Nature 405:220-227. https://doi.org/10.1038/35012228

Gorenflo, L. J., S. Romaine, R. A. Mittermeier, and K. WalkerPainemilla. 2012. Co-occurrence of linguistic and biological diversity in biodiversity hotspots and high biodiversity wilderness areas. Proceedings of the National Academy of Sciences 109 (21):8032-8037. https://doi.org/10.1073/pnas.1117511109

Grivetti, L. E., and B. M. Ogle. 2000. Value of traditional foods in meeting macro- and micronutrient needs: the wild plant connection. Nutrition Research Reviews 13(1):31-46. https://doi. org/10.1079/095442200108728990

Harper, S. L., L. Berrang-Ford, C. Carcamo, A. Cunsolo, V. L. Edge, J. D. Ford, A. Llanos, S. Lwasa, and D. B. Namanya. 2019. The indigenous climate-food-health nexus: indigenous voices, stories, and lived experiences in Canada, Uganda, and Peru. In L. R. Mason and J. Rigg, editors. People and climate change: vulnerability, adaptation, and social justice. Oxford University Press, Oxford, UK. https://doi.org/10.1093/oso/9780190886455.003.0010

Hickey, G. M., M. Pouliot, C. Smith-Hall, S. Wunder, and M. R. Nielsen. 2016. Quantifying the economic contribution of wild food harvests to rural livelihoods: a global-comparative analysis. Food Policy 62:122-132. https://doi.org/10.1016/j.foodpol.2016.06.001

Houde, N. 2007. The six faces of traditional ecological knowledge: challenges and opportunities for Canadian co-management arrangements. Ecology and Society 12(2):34. https://doi. org/10.5751/ES-02270-120234

Jaccard, P. 1901. Étude comparative de la distribution florale dans une portion des Alpes et des Jura. Bulletin de la Societe Vaudoise des Sciences Naturelles 37(142):547-579.

Johnson-Down, L., and G. M. Egeland. 2010. Adequate nutrient intakes are associated with traditional food consumption in Nunavut Inuit children aged 3-5 years. Journal of Nutrition 140 (7):1311-1316. https://doi.org/10.3945/jn.109.117887

Kasimba, S. N., B. S. Motswagole, N. M. Covic, and N. Claasen. 2018. Household access to traditional and indigenous foods positively associated with food security and dietary diversity in Botswana. Public Health Nutrition 21(6):1200-1208. https://doi. org/10.1017/S136898001700369X
Kenny, T.-A., M. Fillion, S. Simpkin, S. D. Wesche, and H. M. Chan. 2018a. Caribou (Rangifer tarandus) and Inuit nutrition security in Canada. EcoHealth 15(3):590-607. https://doi. org/10.1007/s10393-018-1348-Z

Kenny, T.-A., X. F. Hu, H. V. Kuhnlein, S. D. Wesche, and H. M. Chan. 2018b. Dietary sources of energy and nutrients in the contemporary diet of Inuit adults: results from the 2007-08 Inuit Health Survey. Public Health Nutrition 21(7):1319-1331. https:// doi.org/10.1017/S1368980017003810

Kohn, E. 2007. How dogs dream: Amazonian natures and the politics of transspecies engagement. American Ethnologist 34 (1):3-24. https://doi.org/10.1525/ae.2007.34.1.3

Krupnik, I., and D. Jolly, editors. 2002. The Earth is faster now: indigenous observations of Arctic environmental change. Arctic Research Consortium of the United States, Fairbanks, Alaska, USA.

Kuhnlein, H. V., and H. M. Chan. 2000. Environment and contaminants in traditional food systems of northern indigenous peoples. Annual Review of Nutrition 20:595-626. https://doi. org/10.1146/annurev.nutr.20.1.595

Kuhnlein, H. V., B. Erasmus, and D. Spigelski. 2009. Indigenous peoples' food systems: the many dimensions of culture, diversity and environment for nutrition and health. Food and Agriculture Organization, Rome, Italy. [online] URL: http://www.fao.org/3/ $\underline{\mathrm{i} 0370 \mathrm{e} / \mathrm{i} 0370 \mathrm{e} 00 . \mathrm{htm}}$

Kuhnlein, H. V., B. Erasmus, D. Spigelski, and B. Burlingame, editors. 2013. Indigenous peoples' food systems and well-being: interventions and policies for healthy communities. Food and Agriculture Organization of the United Nations, Rome, Italy. [online] URL: http://www.fao.org/3/i3144e/i3144e00.htm

Kuhnlein, H. V., and M. M. Humphries. 2017. Traditional animal foods of indigenous peoples of northern North America: the contributions of wildlife diversity to the subsistence and nutrition of indigenous cultures. Centre for Indigenous Peoples' Nutrition and Environment, McGill University, Montreal, Canada. [online] URL: http://traditionalanimalfoods.org/

Kuhnlein, H. V., and O. Receveur. 1996. Dietary change and traditional food systems of indigenous peoples. Annual Review of Nutrition 16:417-442. https://doi.org/10.1146/annurev. nu.16.070196.002221

Kuhnlein, H. V., and O. Receveur. 2007. Local cultural animal food contributes high levels of nutrients for Arctic Canadian indigenous adults and children. Journal of Nutrition 137 (4):1110-1114. https://doi.org/10.1093/jn/137.4.1110

Kuhnlein, H. V., and N. J. Turner. 1991. Traditional plant foods of Canadian indigenous peoples: nutrition, botany and use. Gordon and Breach, Philadelphia, Pennsylvania, USA.

Laidler, G. J., J. D. Ford, W. A. Gough, T. Ikummaq, A. S. Gagnon, S. Kowal, K. Qrunnut, and C. Irngaut. 2009. Travelling and hunting in a changing Arctic: assessing Inuit vulnerability to sea ice change in Igloolik, Nunavut. Climatic Change 94:363-397. https://doi.org/10.1007/s10584-008-9512-Z

Lambden, J., O. Receveur, and H. V. Kuhnlein. 2007. Traditional food attributes must be included in studies of food security in the 
Canadian Arctic. International Journal of Circumpolar Health 66 (4):308-319. https://doi.org/10.3402/ijch.v66i4.18272

Lewis, S. L., and M. A. Maslin. 2015. Defining the Anthropocene. Nature 519:171-180. https://doi.org/10.1038/nature14258

Liu, J., T. Dietz, S. R. Carpenter, M. Alberti, C. Folke, E. Moran, A. N. Pell, P. Deadman, T. Kratz, J. Lubchenco, E. Ostrom, Z. Ouyang, W. Provencher, C. L. Redman, S. H. Schneider, and W. W. Taylor. 2007. Complexity of coupled human and natural systems. Science 317:1513-1516. https://doi.org/10.1126/science.1144004

Loh, J., and D. Harmon. 2005. A global index of biocultural diversity. Ecological Indicators 5(3):231-241. https://doi. org/10.1016/j.ecolind.2005.02.005

Marean, C. W. 1997. Hunter-gatherer foraging strategies in tropical grasslands: model building and testing in the East African Middle and Later Stone Age. Journal of Anthropological Archaeology 16(3):189-225. https://doi.org/10.1006/jaar.1997.0309

Marsh, G. P. 1864. Man and nature; or, physical geography as modified by human action. Scribner, New York, New York, USA.

Marushka, L., M. Batal, D. Sharp, H. Schwartz, A. Ing, K. Fediuk, A. Black, C. Tikhonov, and H. M. Chan. 2017. Fish consumption is inversely associated with type 2 diabetes in Manitoba First Nations communities. Facets 2:795-818. https:// doi.org/10.1139/facets-2017-0023

McCune, B., J. B. Grace, and D. L. Urban. 2002. Analysis of ecological communities. MjM Software Design, Gleneden Beach, Oregon, USA.

McDonald, R., M. McKnight, D. Weiss, E. Selig, M. O'Connor, C. Violin, and A. Moody. 2005. Species compositional similarity and ecoregions: Do ecoregion boundaries represent zones of high species turnover? Biological Conservation 126(1):24-40. https:// doi.org/10.1016/j.biocon.2005.05.008

McIvor, O., A. Napoleon, and K. M. Dickie. 2013. Language and culture as protective factors for at-risk communities. International Journal of Indigenous Health 5(1):6-25. https://doi.org/10.18357/ ijih51200912327

Milburn, M. P. 2004. Indigenous nutrition: using traditional food knowledge to solve contemporary health problems. American Indian Quarterly 28(3-4):411-434. https://doi.org/10.1353/ aiq.2004.0104

Mitchell, D., and L. Donald. 2001. Sharing resources on the North Pacific coast of North America: the case of the eulachon fishery. Anthropologica 43(1):19-35. [online] URL: https://www. jstor.org/stable/25606007

Mithun, M. 2001. The languages of native North America. Cambridge University Press, Cambridge, UK.

Moran, E. F. 2016. People and nature: an introduction to human ecological relations. Wiley, Hoboken, New Jersey, USA.

Mulrennan, M. E., and V. Bussières. 2018. Social-ecological resilience in indigenous coastal edge contexts. Ecology and Society 23(3):18. https://doi.org/10.5751/ES-10341-230318

Murray, K., and M. M. Conner. 2009. Methods to quantify variable importance: implications for the analysis of noisy ecological data. Ecology 90(2):348-355. https://doi.org/10.1890/07-1929.1
Natcher, D. C. 2009. Subsistence and the social economy of Canada's Aboriginal North. Northern Review 30:83-98. [online] URL: https://thenorthernreview.ca/index.php/nr/article/view/6

Oksanen, J., F. G. Blanchet, M. Friendly, R. Kindt, P. Legendre, D. McGlinn, P. R. Minchin, R. B. O'Hara, G. L. Simpson, P. Solymos, M. H. H. Stevens, E. Szoecs, and H. Wagner. 2018. vegan: community ecology package: ordination methods, diversity analysis and other functions for community and vegetation ecologists. R package version 2.5-2. [online] URL: https://CRAN. R-project.org/package $=$ vegan

Olsson, P., C. Folke, and F. Berkes. 2004. Adaptive comanagement for building resilience in social-ecological systems. Environmental Management 34:75-90. https://doi.org/10.1007/s00267-003-0101-7

Orr, Y., J. S. Lansing, and M. R. Dove. 2015. Environmental anthropology: systemic perspectives. Annual Review of Anthropology 44:153-168. https://doi.org/10.1146/annurevanthro-102214-014159

Ostrom, E. 2009. A general framework for analyzing sustainability of social-ecological systems. Science 325:419-422. https://doi.org/10.1126/science.1172133

Parlee, B. L., E. Goddard, Łutsël K'é Dene First Nation, and M. Smith. 2014. Tracking change: traditional knowledge and monitoring of wildlife health in northern Canada. Human Dimensions of Wildlife 19(1):47-61. https://doi.org/10.1080/1087$\underline{1209.2013 .825823}$

Power, E. M. 2008. Conceptualizing food security for Aboriginal people in Canada. Canadian Journal of Public Health 99:95-97. https://doi.org/10.1007/BF03405452

Quinn, C. L., J. M. Armitage, K. Breivik, and F. Wania. 2012. A methodology for evaluating the influence of diets and intergenerational dietary transitions on historic and future human exposure to persistent organic pollutants in the Arctic. Environment International 49:83-91. https://doi.org/10.1016/j. envint.2012.08.014

R Core Team. 2019. R: a language and environment for statistical computing. R Foundation for Statistical Computing, Vienna, Austria. [online] URL: https://www.r-project.org/

Ready, E. 2018. Sharing-based social capital associated with harvest production and wealth in the Canadian Arctic. Plos One 13(3):e0193759. https://doi.org/10.1371/journal.pone.0193759

Robertson, S., and G. Ljubicic. 2019. Nunamii'luni quvianaqtuq (It is a happy moment to be on the land): feelings, freedom and the spatial political ontology of well-being in Gjoa Haven and Tikiranajuk, Nunavut. Environment and Planning D: Society and Space 37(3):542-560. https://doi.org/10.1177/0263775818821129

Royer, M.-J. S. 2015. Climate, environment and Cree observations: James Bay Territory, Canada. Springer, Cham, Switzerland.

Salmón, E. 2000. Kincentric ecology: indigenous perceptions of the human-nature relationship. Ecological Applications 10 (5):1327-1332. https://doi.org/10.1890/1051-0761(2000)010[1327: KEIPOT]2.0.CO;2

Schlüter, M., J. Hinkel, P. W. G. Bots, and R. Arlinghaus. 2014. Application of the SES framework for model-based analysis of 
the dynamics of social-ecological systems. Ecology and Society 19(1):36. http://dx.doi.org/10.5751/ES-05782-190136

Semali, L. M., and J. L. Kincheloe. 2002. What is indigenous knowledge? Voices from the academy. Routledge, New York, New York, USA. https://doi.org/10.4324/9780203906804

Soininen, J., R. McDonald, and H. Hillebrand. 2007. The distance decay of similarity in ecological communities. Ecography 30 (1):3-12. https://doi.org/10.1111/j.0906-7590.2007.04817.x

Stevens, S., editors. 1997. Conservation through cultural survival: indigenous peoples and protected areas. Island Press, Washington, D.C., USA.

Swinburn, B. A., V. I. Kraak, S. Allender, V. J. Atkins, P. I. Baker, J. R. Bogard, H. Brinsden, A. Calvillo, O. De Schutter, R. Devarajan, M. Ezzati, S. Friel, S. Goenka, R. A. Hammond, G. Hastings, C. Hawkes, M. Herrero, P. S. Hovmand, M. Howden, L. M. Jaacks, A. B. Kapetanaki, M. Kasman, H. V. Kuhnlein, S. K. Kumanyika, B. Larijani, T. Lobstein, M. W. Long, V. K. R. Matsudo, S. D. H. Mills, G. Morgan, A. Morshed, P. M. Nece, A. Pan, D. W. Patterson, G. Sacks, M. Shekar, G. L. Simmons, W. Smit, A. Tootee, S. Vandevijvere, W. E. Waterlander, L. Wolfenden, and W. H. Dietz. 2019. The global syndemic of obesity, undernutrition, and climate change: The Lancet Commission report. The Lancet 393:791-846. https://doi. org/10.1016/S0140-6736(18)32822-8

Thompson, F. E., and A. F. Subar. 2017. Dietary assessment methodology. in A. Coulston, C. Boushey, M. Ferruzzi, and L. Delahanty, editors. Nutrition in the prevention and treatment of disease. Fourth edition. Academic Press, Amsterdam, The Netherlands.

Turnbull, C. 1987. The mountain people. Simon and Schuster, New York, New York, USA.

Turner, N. J. 1995. Food plants of coastal First Peoples. UBC Press, Vancouver, Canada.

Turner, N. J., I. J. Davidson-Hunt, and M. O'Flaherty. 2003. Living on the edge: ecological and cultural edges as sources of diversity for social-ecological resilience. Human Ecology 31:439-461. https://doi.org/10.1023/A:1025023906459

Wassmann, P., C. M. Duarte, S. Agustí, and M. K. Sejr. 2011. Footprints of climate change in the Arctic marine ecosystem. Global Change Biology 17(2):1235-1249. https://doi.org/10.1111/ j.1365-2486.2010.02311.x

Wein, E. E., and M. M. R. Freeman. 1995. Frequency of traditional food use by three Yukon First Nations living in four communities. Arctic 48(2):109-206. https://doi.org/10.14430/ arctic1238

Wein, E. E., M. M. R. Freeman, and J. C. Makus. 1996. Use of and preference for traditional foods among the Belcher Island Inuit. Arctic 49(3):211-320. https://doi.org/10.14430/arctic1201

Wenzel, G. 1991. Animal rights, human rights: ecology, economy, and ideology in the Canadian Arctic. University of Toronto Press, Toronto, Canada. https://doi.org/10.3138/9781442670877

Young, T. K., J. Reading, B. Elias, and J. D. O’Neil. 2000. Type 2 diabetes mellitus in Canada's First Nations: status of an epidemic in progress. Canadian Medical Association Journal 163 (5):561-566. [online] URL: https://www.cmaj.ca/content/163/5/561. $\underline{\text { full }}$

Zaccarelli, N., D. I. Bolnick, and G. Mancinelli. 2013. RInSp: an $\mathrm{R}$ package for the analysis of individual specialization in resource use. Methods in Ecology and Evolution 4(11):1018-1023. https:// doi.org/10.1111/2041-210X.12079

Zimmerer, K. S., H. Córdova-Aguilar, R. Mata Olmo, Y. Jiménez Olivencia, and S. J. Vanek. 2017. Mountain ecology, remoteness, and the rise of agrobiodiversity: tracing the geographic spaces of human-environment knowledge. Annals of the American Association of Geographers 107(2):441-455. https://doi. org/10.1080/24694452.2016.1235482 
Appendix 1. Culture of local food use: supplementary information

Table A1.1. Communities or regional community groups included in this analysis, including cultural and linguistic groupings, and dietary data sources.

\begin{tabular}{|c|c|c|c|c|}
\hline $\begin{array}{l}\text { Community, Community Pair, or Region } \\
\text { included as unit of analyses (indicates } \\
\text { abbreviation used in figures) }\end{array}$ & Culture & $\begin{array}{l}\text { First Nations } \\
\text { Language } \\
\text { Family } \\
\text { / Inuit Region }\end{array}$ & $\begin{array}{l}\text { Inuit (I) } \\
\text { or First } \\
\text { Nations } \\
\text { (FN) }\end{array}$ & Source $\dagger$ \\
\hline Kugaaruk (KR) & Netsilik & $\begin{array}{l}\text { Nunavut } \\
\text { Kitikmeot }\end{array}$ & I & 1 \\
\hline Sanikiluaq (SN) & Qikirtamiut & $\begin{array}{l}\text { Nunavut } \\
\text { Qikigtaaluk }\end{array}$ & I & 2 \\
\hline Qikiqtarjuak (QI) & Nunatsiarmuit & $\begin{array}{l}\text { Nunavut } \\
\text { Qikiqtaaluk }\end{array}$ & I & 3 \\
\hline $\begin{array}{l}\text { Nunavik - Hudson Bay (HB) } \\
\text { (including Akulivik, Puvirnituq, Inukjuak, } \\
\text { Umiujaq, Kuujjuarapik) }\end{array}$ & Nunavimmiut & Nunavik & I & 4 \\
\hline $\begin{array}{l}\text { Nunavik - Hudson Strait (HS) (including } \\
\text { Ivujivik, Salluit, Kangiqsujuaq, Quaqtaq) }\end{array}$ & Nunavimmiut & Nunavik & I & 4 \\
\hline $\begin{array}{l}\text { Nunavik - Ungava Bay (UB) } \\
\text { (including Kangirsuk, Aupaluk, Tasiujaq, } \\
\text { Kuujjuaq, Kangiqsualujjuaq) }\end{array}$ & Nunavimmiut & Nunavik & I & 4 \\
\hline Kangiqsujuaq (KA) & Nunavimmiut & Nunavik & $\mathrm{I}$ & 5 \\
\hline Old Crow (OC) & Vuntut Gwitchin & Athabaskan & FN & 6 \\
\hline Fort Good Hope (FGH) \& Colville Lake (CL) & $\begin{array}{l}\text { Sahtu Dene \& } \\
\text { Metis }\end{array}$ & Athabaskan & FN & 7 \\
\hline Fort Providence (FP) & Dehcho Dene & Athabaskan & FN & 8 \\
\hline Fort Smith (FSm) \& Fort Chipewyan (FC) & $\begin{array}{l}\text { Akaitcho Dene \& } \\
\text { Athabaskan Tribal } \\
\text { Council }\end{array}$ & Athabaskan & FN & 9 \\
\hline Haines Junction (HJ) & $\begin{array}{l}\text { Champagne \& } \\
\text { Aishihik }\end{array}$ & Athabaskan & FN & 6 \\
\hline Teslin (TE) & Teslin Tlingit & Tlingit & FN & 6 \\
\hline Fort Severn (FSe) & $\begin{array}{l}\text { Cree Nishnawbe } \\
\text { Aski Nation }\end{array}$ & Algonquian & FN & 10 \\
\hline Mistissini (MI) & $\begin{array}{l}\text { Cree Eeyou } \\
\text { Istchee }\end{array}$ & Algonquian & FN & 11 \\
\hline Waswanipi (WA) & $\begin{array}{l}\text { Cree Eeyou } \\
\text { Istchee }\end{array}$ & Algonquian & FN & 12 \\
\hline Eastmain (EA) & $\begin{array}{l}\text { Cree Eeyou } \\
\text { Istchee }\end{array}$ & Algonquian & FN & 12 \\
\hline Waskaganish (WK) & $\begin{array}{l}\text { Cree Eeyou } \\
\text { Istchee }\end{array}$ & Algonquian & FN & 12 \\
\hline Chisasibi (CH) & $\begin{array}{l}\text { Cree Eeyou } \\
\text { Istchee }\end{array}$ & Algonquian & FN & 12 \\
\hline Whapmagoostui (WH) & $\begin{array}{l}\text { Cree Eeyou } \\
\text { Istchee }\end{array}$ & Algonquian & FN & 12 \\
\hline Wemindji (WE) & $\begin{array}{l}\text { Cree Eeyou } \\
\text { Istchee }\end{array}$ & Algonquian & FN & 12 \\
\hline
\end{tabular}


$\dagger$ Dietary data sources are:

${ }^{1}$ Lawn, J. \& Harvey, D. Nutrition and food security in Kugaaruk, Nunavut. Minister of Indian Affairs and Northern Development, Ottawa, Ont (2003).

${ }^{2}$ Wein, E. E., Freeman, M. M. \& Makus, J. C. Use of and preference for traditional foods among the Belcher Island Inuit. Arctic, 256-264 (1996).

${ }^{3}$ Kuhnlein, H. V. \& Soueida, R. Use and nutrient composition of traditional Baffin Inuit foods. Journal of Food Composition and Analysis 5, 112-126 (1992).

${ }^{4}$ Lemire, M. et al. Local country food sources of methylmercury, selenium and omega-3 fatty acids in Nunavik, Northern Quebec. Science of the Total Environment 509, 248-259 (2015).

${ }^{5}$ Lawn, J. \& Harvey, D. Nutrition and food security in Kangiqsujuaq, Nunavik. Ottawa, ON: Minister of Indian Affairs and Northern Development (2004).

${ }^{6}$ Wein, E. E. \& Freeman, M. M. Frequency of traditional food use by three Yukon First Nations living in four communities. Arctic, 161-171 (1995).

${ }^{7}$ Morrison, N. et al. Contemporary Sahtu Dene/Metis use of traditional and market food. Ecology of food and nutrition 34, 197-210 (1995).

${ }^{8}$ Guyot, M. \& Chan, H. Impacts of climate change on traditional food security in Aboriginal communities in northern Canada, McGill University, (2006).

${ }^{9}$ Wein, E. E., Sabry, J. H. \& Evers, F. T. Food consumption patterns and use of country foods by native Canadians near Wood Buffalo National Park, Canada. Arctic, 196-205 (1991).

${ }^{10}$ Lawn, J. \& Harvey, D. Nutrition and food security in Fort Severn, Ontario. Minister of Indian Affairs and Northern Development, Ottawa, Ont (2004).

${ }^{11}$ Bonnier-Viger, Y., Dewailly, E., Egeland, G., Nieboer, E. \& Pereg, D. Nituuchischaayihtitaau Aschii. Multicommunity Environment-and Health longitudinal study in IIyiyiu Aschii: Mistissini. Technical report: Summary of activities, results and recommendations. Montreal, QC: Cree Board of Health and Social Services of James Bay, 389 (2007).

${ }^{12}$ Ayotte, P., Fontaine, J., Martin, I., Nieboer, E. \& Lejeune, P. Environmental contaminants in Nituuchischaayihtitaau Aschii multi-community environment and health longitudinal study in Eeyou Istchee: Eastmain and Wemindji technical report: Summary of 2007 activities, results and recommendations, ed. E. Nieboer, E. Robinson and K. Petrov, Cree Board of Health and Social Services of James Bay, Chisasibi, Québec, 102-162 (2011). 
Table A1.2. Cross-study standardization matrix of community-by-species dietary importance values (\%).

\begin{tabular}{|c|c|c|c|c|c|c|c|c|}
\hline Community & Caribou & Moose & Bison & Goat & $\begin{array}{l}\text { Mountain } \\
\text { sheep }\end{array}$ & Beaver & Hare & Muskrat \\
\hline Fort Severn & 41.91 & 7.07 & 0 & 0 & 0 & 0.49 & 4.14 & 0 \\
\hline Mistissini & 10.11 & 15.89 & 0 & 0 & 0 & 2.64 & 2.62 & 0 \\
\hline Waswanipi & 2.62 & 26.77 & 0 & 0 & 0 & 3.35 & 8.69 & 0 \\
\hline Eastmain & 5.31 & 15.61 & 0 & 0 & 0 & 4.6 & 4.81 & 0 \\
\hline Waskaganish & 7.51 & 14.59 & 0 & 0 & 0 & 3.37 & 4.45 & 0 \\
\hline Chisasibi & 9.72 & 6.33 & 0 & 0 & 0 & 2 & 3.21 & 0 \\
\hline Whapmagoostui & 17.44 & 2.23 & 0 & 0 & 0 & 1.32 & 0.57 & 0 \\
\hline Wemindji & 9.06 & 11.66 & 0 & 0 & 0 & 4.21 & 4.17 & 0 \\
\hline Fort Providence & 19.83 & 21.49 & 0 & 0 & 0 & 4.13 & 9.09 & 2.48 \\
\hline $\begin{array}{l}\text { Fort Good Hope \& } \\
\text { Colville Lake }\end{array}$ & 30.81 & 20.15 & 0 & 0 & 0 & 3.61 & 10.19 & 0 \\
\hline Old Crow & 62.6 & 7.61 & 0 & 0 & 0 & 0.34 & 4.68 & 1.72 \\
\hline $\begin{array}{l}\text { Fort Smith \& Fort } \\
\text { Chipewyan }\end{array}$ & 21.29 & 23.29 & 6.02 & 0 & 0 & 1.2 & 7.23 & 2.01 \\
\hline Kangiqsujuaq & 20.7 & 0 & 0 & 0 & 0 & 0 & 0 & 0 \\
\hline $\begin{array}{l}\text { Nunavik (Eastern } \\
\text { Hudson Bay) }\end{array}$ & 28.68 & 0 & 0 & 0 & 0 & 0 & 0.04 & 0 \\
\hline $\begin{array}{l}\text { Nunavik (Hudson } \\
\text { Strait) }\end{array}$ & 27.69 & 0 & 0 & 0 & 0 & 0 & 0.06 & 0 \\
\hline $\begin{array}{l}\text { Nunavik (Ungava } \\
\text { Bay) }\end{array}$ & 34.89 & 0 & 0 & 0 & 0 & 0 & 0.07 & 0 \\
\hline Kugaaruk & 35.65 & 0 & 0 & 0 & 0 & 0 & 0 & 0 \\
\hline Sanikiluaq & 3.87 & 0 & 0 & 0 & 0 & 0 & 0.31 & 0 \\
\hline Qikiqtarjuak & 12.68 & 0 & 0 & 0 & 0 & 0 & 2.31 & 0 \\
\hline Teslin & 1.58 & 56.09 & 0 & 0.11 & 2.36 & 2.19 & 1.28 & 0 \\
\hline Haines Junction & 2.97 & 42.34 & 0.05 & 0 & 5.45 & 0.09 & 1.17 & 0.09 \\
\hline
\end{tabular}


Table A1.2. Continued.

\begin{tabular}{|c|c|c|c|c|c|c|c|c|}
\hline Community & $\begin{array}{l}\text { Arctic } \\
\text { fox }\end{array}$ & Lynx & $\begin{array}{l}\text { Ringed } \\
\text { seal }\end{array}$ & $\begin{array}{l}\text { Bearded } \\
\text { seal }\end{array}$ & Narwhal & Beluga & Walrus & $\begin{array}{l}\text { Unspecified } \\
\text { marine } \\
\text { mammals }\end{array}$ \\
\hline Fort Severn & 0 & 0 & 0 & 0 & 0 & 0 & 0 & 0 \\
\hline Mistissini & 0 & 0 & 0 & 0 & 0 & 0 & 0 & 0 \\
\hline Waswanipi & 0 & 0 & 0 & 0 & 0 & 0 & 0 & 0 \\
\hline Eastmain & 0 & 0 & 0 & 0 & 0 & 0 & 0 & 0 \\
\hline Waskaganish & 0 & 0 & 0 & 0 & 0 & 0 & 0 & 0 \\
\hline Chisasibi & 0 & 0 & 0 & 0 & 0 & 0 & 0 & 0 \\
\hline Whapmagoostui & 0 & 0 & 0 & 0 & 0 & 0 & 0 & 0 \\
\hline Wemindji & 0 & 0 & 0 & 0 & 0 & 0 & 0 & 0 \\
\hline Fort Providence & 0 & 0 & 0 & 0 & 0 & 0 & 0 & 0 \\
\hline $\begin{array}{l}\text { Fort Good Hope \& } \\
\text { Colville Lake }\end{array}$ & 0 & 0 & 0 & 0 & 0 & 0 & 0 & 0 \\
\hline Old Crow & 0 & 0.03 & 0 & 0 & 0 & 0 & 0 & 0 \\
\hline $\begin{array}{l}\text { Fort Smith \& Fort } \\
\text { Chipewyan }\end{array}$ & 0 & 0.4 & 0 & 0 & 0 & 0 & 0 & 0 \\
\hline Kangiqsujuaq & 0 & 0 & 11.35 & 1.26 & 0 & 0 & 0 & 7.65 \\
\hline $\begin{array}{l}\text { Nunavik (Eastern } \\
\text { Hudson Bay) }\end{array}$ & 0.08 & 0 & 5.77 & 0.64 & 0 & 6.57 & 0.49 & 0.16 \\
\hline $\begin{array}{l}\text { Nunavik (Hudson } \\
\text { Strait) }\end{array}$ & 0 & 0 & 4.56 & 0.51 & 0 & 24.18 & 0.75 & 0.23 \\
\hline $\begin{array}{l}\text { Nunavik (Ungava } \\
\text { Bay) }\end{array}$ & 0 & 0 & 5.33 & 0.59 & 0 & 8.3 & 0.2 & 0.2 \\
\hline Kugaaruk & 0 & 0 & 0 & 0 & 0 & 0 & 0 & 8.49 \\
\hline Sanikiluaq & 0.1 & 0 & 12.75 & 2.61 & 0 & 2.72 & 1.15 & 0 \\
\hline Qikiqtarjuak & 0 & 0 & 21.61 & 7.49 & 11.24 & 7.2 & 12.97 & 0 \\
\hline Teslin & 0 & 0.11 & 0 & 0 & 0 & 0 & 0 & 0 \\
\hline Haines Junction & 0 & 0.09 & 0 & 0 & 0 & 0 & 0 & 0 \\
\hline
\end{tabular}


Table A1.2. Continued.

\begin{tabular}{|c|c|c|c|c|c|c|c|c|}
\hline Community & $\begin{array}{l}\text { Black } \\
\text { bear }\end{array}$ & $\begin{array}{l}\text { Polar } \\
\text { bear }\end{array}$ & $\begin{array}{l}\text { Grizzly } \\
\text { bear }\end{array}$ & $\begin{array}{l}\text { Ground } \\
\text { squirrel }\end{array}$ & Porcupine & Marmot & Trout & "Whitefish/Cisco \\
\hline Fort Severn & 0 & 0 & 0 & 0 & 0 & 0 & 6.43 & 4.14 \\
\hline Mistissini & 6.46 & 0 & 0 & 0 & 0 & 0 & 7.1 & 3.57 \\
\hline Waswanipi & 7.96 & 0 & 0 & 0 & 0 & 0 & 2.48 & 1.4 \\
\hline Eastmain & 6.65 & 0 & 0 & 0 & 0 & 0 & 6.57 & 1.13 \\
\hline Waskaganish & 9.17 & 0 & 0 & 0 & 0 & 0 & 6.34 & 5.43 \\
\hline Chisasibi & 9.98 & 0 & 0 & 0 & 0 & 0 & 7.1 & 9.94 \\
\hline Whapmagoostui & 6.57 & 0 & 0 & 0 & 0 & 0 & 9.55 & 4.21 \\
\hline Wemindji & 6 & 0 & 0 & 0 & 0 & 0 & 6.47 & 5.49 \\
\hline Fort Providence & 0 & 0 & 0 & 0 & 0 & 0 & 4.13 & 17.36 \\
\hline $\begin{array}{l}\text { Fort Good Hope \& } \\
\text { Colville Lake }\end{array}$ & 0 & 0 & 0 & 0 & 0 & 0 & 2.32 & 21.54 \\
\hline Old Crow & 0.05 & 0 & 0 & 0.1 & 0.26 & 0 & 0 & 5.51 \\
\hline $\begin{array}{l}\text { Fort Smith \& Fort } \\
\text { Chipewyan }\end{array}$ & 0.4 & 0 & 0.4 & 0 & 0 & 0 & 2.41 & 13.25 \\
\hline Kangiqsujuaq & 0 & 0 & 0 & 0 & 0 & 0 & 0 & 0 \\
\hline $\begin{array}{l}\text { Nunavik (Eastern } \\
\text { Hudson Bay) }\end{array}$ & 0 & 0.29 & 0 & 0 & 0 & 0 & 1.89 & 6.53 \\
\hline $\begin{array}{l}\text { Nunavik (Hudson } \\
\text { Strait) }\end{array}$ & 0 & 0.17 & 0 & 0 & 0 & 0 & 0.35 & 0.69 \\
\hline $\begin{array}{l}\text { Nunavik (Ungava } \\
\text { Bay) }\end{array}$ & 0 & 0.07 & 0 & 0 & 0 & 0 & 2.57 & 2.24 \\
\hline Kugaaruk & 0 & 3.06 & 0 & 0 & 0 & 0 & 0 & 6.79 \\
\hline Sanikiluaq & 0 & 0.31 & 0 & 0 & 0 & 0 & 0 & 6.06 \\
\hline Qikiqtarjuak & 0 & 4.61 & 0 & 0 & 0 & 0 & 0 & 0 \\
\hline Teslin & 0.22 & 0 & 0 & 0.28 & 0.36 & 0.33 & 5.8 & 10.21 \\
\hline Haines Junction & 0.09 & 0 & 0 & 8.02 & 0.05 & 0.05 & 3.69 & 3.96 \\
\hline
\end{tabular}


Table A1.2. Continued.

\begin{tabular}{|c|c|c|c|c|c|c|c|c|}
\hline Community & Suckers & Pike & Burbot & Grayling & Walleye & Goldeye & Salmon & Sturgeon \\
\hline Fort Severn & 0 & 1.71 & 2.19 & 0 & 0.49 & 0 & 0 & 0 \\
\hline Mistissini & 4.17 & 2.97 & 3.98 & 0 & 3.75 & 0 & 0 & 1.38 \\
\hline Waswanipi & 1.47 & 2.41 & 0.28 & 0 & 6.07 & 0 & 0 & 2.51 \\
\hline Eastmain & 2.97 & 3.81 & 6.28 & 0 & 2.26 & 0 & 0 & 1.72 \\
\hline Waskaganish & 0 & 3.91 & 0.31 & 0 & 4.37 & 0 & 0 & 2.2 \\
\hline Chisasibi & 2.1 & 2.7 & 0.73 & 0 & 2.66 & 0 & 0 & 0.65 \\
\hline Whapmagoostui & 0.66 & 2.29 & 0.66 & 0 & 0.41 & 0 & 0 & 0.25 \\
\hline Wemindji & 3.36 & 3.06 & 0.72 & 0 & 3.79 & 0 & 0 & 1.74 \\
\hline Fort Providence & 0 & 0 & 8.26 & 0 & 0 & 0 & 0 & 0 \\
\hline $\begin{array}{l}\text { Fort Good Hope \& } \\
\text { Colville Lake }\end{array}$ & 0 & 0.23 & 2.34 & 0 & 0 & 0 & 0 & 0 \\
\hline Old Crow & 0.1 & 0.03 & 1.69 & 1.04 & 0 & 0 & 6.72 & 0 \\
\hline $\begin{array}{l}\text { Fort Smith \& Fort } \\
\text { Chipewyan }\end{array}$ & 0.8 & 3.61 & 0.4 & 0 & 3.61 & 0.8 & 0 & 0 \\
\hline Kangiqsujuaq & 0 & 0 & 0 & 0 & 0 & 0 & 0 & 0 \\
\hline $\begin{array}{l}\text { Nunavik (Eastern } \\
\text { Hudson Bay) }\end{array}$ & 0 & 0 & 0 & 0 & 0 & 0 & 1.89 & 0 \\
\hline $\begin{array}{l}\text { Nunavik (Hudson } \\
\text { Strait) }\end{array}$ & 0 & 0 & 0 & 0 & 0 & 0 & 0.35 & 0 \\
\hline $\begin{array}{l}\text { Nunavik (Ungava } \\
\text { Bay) }\end{array}$ & 0 & 0 & 0 & 0 & 0 & 0 & 2.57 & 0 \\
\hline Kugaaruk & 0 & 0 & 0 & 0 & 0 & 0 & 0 & 0 \\
\hline Sanikiluaq & 0 & 0 & 0 & 0 & 0 & 0 & 0 & 0 \\
\hline Qikiqtarjuak & 0 & 0 & 0 & 0 & 0 & 0 & 0 & 0 \\
\hline Teslin & 0 & 0.44 & 0.58 & 1.5 & 0 & 0 & 11.66 & 0 \\
\hline Haines Junction & 0.32 & 0.32 & 0.9 & 1.71 & 0 & 0 & 19.77 & 0 \\
\hline
\end{tabular}


Table A1.2. Continued.

\begin{tabular}{|c|c|c|c|c|c|c|c|c|}
\hline Community & Eulachon & $\begin{array}{l}\text { Arctic } \\
\text { char/Dolly } \\
\text { varden }\end{array}$ & Cod & Sculpin & $\begin{array}{l}\text { Unspecified } \\
\text { fish }\end{array}$ & $\begin{array}{l}\text { Unspecified } \\
\text { birds }\end{array}$ & Ducks & Geese \\
\hline Fort Severn & 0 & 1.46 & 0 & 0 & 0 & 0 & 0 & 24.85 \\
\hline Mistissini & 0 & 0 & 0 & 0 & 6.21 & 0 & 11.45 & 11.45 \\
\hline Waswanipi & 0 & 0 & 0 & 0 & 5.02 & 0 & 6.84 & 12.04 \\
\hline Eastmain & 0 & 0 & 0 & 0 & 5.52 & 0 & 10.63 & 13.89 \\
\hline Waskaganish & 0 & 0 & 0 & 0 & 10.25 & 0 & 7.17 & 15.65 \\
\hline Chisasibi & 0 & 0 & 0 & 0 & 8.45 & 0 & 11.64 & 15.21 \\
\hline Whapmagoostui & 0 & 0 & 0 & 0 & 7.41 & 0 & 6.57 & 22.47 \\
\hline Wemindji & 0 & 0 & 0 & 0 & 12.98 & 0 & 6.94 & 14.17 \\
\hline Fort Providence & 0 & 0 & 0 & 0 & 0 & 0 & 0 & 0 \\
\hline $\begin{array}{l}\text { Fort Good Hope \& } \\
\text { Colville Lake }\end{array}$ & 0 & 0 & 0 & 0 & 0 & 0 & 7.88 & 0.46 \\
\hline Old Crow & 0.05 & 0.03 & 0 & 0 & 0 & 0.21 & 3.72 & 2.18 \\
\hline $\begin{array}{l}\text { Fort Smith \& Fort } \\
\text { Chipewyan }\end{array}$ & 0 & 0 & 0 & 0 & 0.4 & 0 & 5.22 & 2.01 \\
\hline Kangiqsujuaq & 0 & 22.06 & 0 & 0 & 0 & 0 & 0 & 9.25 \\
\hline $\begin{array}{l}\text { Nunavik (Eastern } \\
\text { Hudson Bay) }\end{array}$ & 0 & 18.98 & 1.23 & 1.07 & 0 & 0.62 & 0 & 13.68 \\
\hline $\begin{array}{l}\text { Nunavik (Hudson } \\
\text { Strait) }\end{array}$ & 0 & 16.7 & 0.35 & 2.07 & 0 & 0.17 & 0 & 7.89 \\
\hline $\begin{array}{l}\text { Nunavik (Ungava } \\
\text { Bay) }\end{array}$ & 0 & 19.62 & 0.13 & 0.53 & 0 & 0.33 & 0 & 9.22 \\
\hline Kugaaruk & 0 & 46.01 & 0 & 0 & 0 & 0 & 0 & 0 \\
\hline Sanikiluaq & 0 & 9.4 & 3.55 & 3.03 & 0 & 1.88 & 11.81 & 12.43 \\
\hline Qikiqtarjuak & 0 & 6.34 & 0 & 0 & 0 & 1.44 & 2.31 & 1.15 \\
\hline Teslin & 0 & 0.5 & 0 & 0 & 0 & 0.22 & 1.75 & 0.5 \\
\hline Haines Junction & 0.54 & 0.23 & 0 & 0 & 0 & 0.09 & 3.69 & 0.27 \\
\hline
\end{tabular}


Table A1.2. Continued.

\begin{tabular}{|c|c|c|c|c|c|c|c|}
\hline Community & Swan & Ptarmigan/Grouse & Clams & Mussels & Scallops & $\begin{array}{l}\text { Sea } \\
\text { urchin }\end{array}$ & $\begin{array}{l}\text { Sea } \\
\text { cucumber }\end{array}$ \\
\hline Fort Severn & 0 & 5.12 & 0 & 0 & 0 & 0 & 0 \\
\hline Mistissini & 0 & 4.6 & 0 & 0 & 0 & 0 & 0 \\
\hline Waswanipi & 0 & 4.12 & 0 & 0 & 0 & 0 & 0 \\
\hline Eastmain & 0 & 4.06 & 0 & 0 & 0 & 0 & 0 \\
\hline Waskaganish & 0 & 3.2 & 0 & 0 & 0 & 0 & 0 \\
\hline Chisasibi & 0 & 4.36 & 0 & 0 & 0 & 0 & 0 \\
\hline Whapmagoostui & 0 & 12.63 & 0 & 0 & 0 & 0 & 0 \\
\hline Wemindji & 0 & 5.28 & 0 & 0 & 0 & 0 & 0 \\
\hline Fort Providence & 0 & 13.22 & 0 & 0 & 0 & 0 & 0 \\
\hline $\begin{array}{l}\text { Fort Good Hope \& } \\
\text { Colville Lake }\end{array}$ & 0 & 0.46 & 0 & 0 & 0 & 0 & 0 \\
\hline Old Crow & 0 & 0.83 & 0 & 0 & 0 & 0 & 0 \\
\hline $\begin{array}{l}\text { Fort Smith \& Fort } \\
\text { Chipewyan }\end{array}$ & 0.4 & 3.21 & 0 & 0 & 0 & 0 & 0 \\
\hline Kangiqsujuaq & 0 & 24.99 & 0 & 0 & 0 & 0 & 0 \\
\hline $\begin{array}{l}\text { Nunavik (Eastern } \\
\text { Hudson Bay) }\end{array}$ & 0 & 5.79 & 0.08 & 2.71 & 0.04 & 0 & 0 \\
\hline $\begin{array}{l}\text { Nunavik (Hudson } \\
\text { Strait) }\end{array}$ & 0 & 4.55 & 0.81 & 4.66 & 0.4 & 0 & 0 \\
\hline Nunavik (Ungava Bay) & 0 & 7.18 & 0.26 & 2.96 & 0.13 & 0 & 0 \\
\hline Kugaaruk & 0 & 0 & 0 & 0 & 0 & 0 & 0 \\
\hline Sanikiluaq & 0 & 0.31 & 0 & 9.93 & 0 & 9.09 & 8.67 \\
\hline Qikiqtarjuak & 0 & 2.59 & 2.88 & 3.17 & 0 & 0 & 0 \\
\hline Teslin & 0.03 & 1.19 & 0 & 0 & 0 & 0 & 0 \\
\hline Haines Junction & 0.09 & 3.96 & 0 & 0 & 0 & 0 & 0 \\
\hline
\end{tabular}


Table A1.3a. Pairwise community cultural relatedness measure ranging from a maximum value of 4 for community pairs sharing a cultural group, language family, and language (e.g., multiple Cree communities in Eeyou Istchee), to a minimum value of 1 for community pairs belonging to distinct cultural groups (e.g., Inuit and First Nations), and therefore distinct language families and languages. Community or region name abbreviations are: Fort Severn (FSe), Mistissini (MI), Waswanipi (WA), Eastmain (EA), Waskaganish (WK), Chisasibi (CH), Whapmagoostui (WH), Wemindji (WE), Teslin (TE), Haines Junction (HJ), Old Crow (OC), Fort Good Hope \& Colville Lake (FGH \& CL), Fort Providence (FP), Fort Smith \& Fort Chipewyan (FSm \& FC), Kangiqsujuaq (KA), Hudson Bay (HB, including Akulivik, Puvirnituq, Inukjuak, Umiujaq, Kuujjuarapik), Hudson Strait (HS, including Ivujivik, Salluit, Kangiqsujuaq, Quaqtaq), Ungava Bay (UB, including Kangirsuk, Aupaluk, Tasiujaq, Kuujjuaq, Kangiqsualujjuaq), Sanikiluaq (SN), Qikiqtarjuaq (QI), Kugaaruk (KR).

\begin{tabular}{|l|c|c|c|c|c|c|c|c|c|c|c|c|c|c|c|c|c|c|c|c|c|c|}
\hline Community & Fse & MI & WA & EA & WK & CH & WH & WE & TE & HJ & OC & FGH \& CL & FP & FSm \& FC & KA & HB & HS & UB & SN & QI & KR \\
\hline Fse & & & & & & & & & & & & & & & & & & & & & & \\
\hline MI & 3 & & & & & & & & & & & & & & & & & & & & \\
\hline WA & 3 & 4 & & & & & & & & & & & & & & & & & & & \\
\hline EA & 3 & 4 & 4 & & & & & & & & & & & & & & & & & & \\
\hline WK & 3 & 4 & 4 & 4 & & & & & & & & & & & & & & & & & \\
\hline CH & 3 & 4 & 4 & 4 & 4 & & & & & & & & & & & & & & & & \\
\hline WH & 3 & 4 & 4 & 4 & 4 & 4 & & & & & & & & & & & & & & & \\
\hline WE & 3 & 4 & 4 & 4 & 4 & 4 & 4 & & & & & & & & & & & & & & \\
\hline TE & 2 & 2 & 2 & 2 & 2 & 2 & 2 & 2 & & & & & & & & & & & & & \\
\hline HJ & 2 & 2 & 2 & 2 & 2 & 2 & 2 & 2 & 3 & & & & & & & & & & & & \\
\hline OC & 2 & 2 & 2 & 2 & 2 & 2 & 2 & 2 & 3 & 3 & & & & & & & & & & & \\
\hline FGH \& CL & 2 & 2 & 2 & 2 & 2 & 2 & 2 & 2 & 3 & 3 & 3 & & & & & & & & & & \\
\hline FP & 2 & 2 & 2 & 2 & 2 & 2 & 2 & 2 & 3 & 3 & 3 & 3 & & & & & & & & & \\
\hline FSm \& FC & 2 & 2 & 2 & 2 & 2 & 2 & 2 & 2 & 3 & 3 & 3 & 3 & 3 & & & & & & & & \\
\hline KA & 1 & 1 & 1 & 1 & 1 & 1 & 1 & 1 & 1 & 1 & 1 & 1 & 1 & 1 & & & & & & & \\
\hline HB & 1 & 1 & 1 & 1 & 1 & 1 & 1 & 1 & 1 & 1 & 1 & 1 & 1 & 1 & 3 & & & & & & \\
\hline HS & 1 & 1 & 1 & 1 & 1 & 1 & 1 & 1 & 1 & 1 & 1 & 1 & 1 & 1 & 4 & 3 & & & & & \\
\hline UB & 1 & 1 & 1 & 1 & 1 & 1 & 1 & 1 & 1 & 1 & 1 & 1 & 1 & 1 & 3 & 3 & 3 & & & & \\
\hline SN & 1 & 1 & 1 & 1 & 1 & 1 & 1 & 1 & 1 & 1 & 1 & 1 & 1 & 1 & 2 & 2 & 2 & 2 & & & \\
\hline QI & 1 & 1 & 1 & 1 & 1 & 1 & 1 & 1 & 1 & 1 & 1 & 1 & 1 & 1 & 2 & 2 & 2 & 2 & 3 & & \\
\hline KR & 1 & 1 & 1 & 1 & 1 & 1 & 1 & 1 & 1 & 1 & 1 & 1 & 1 & 1 & 2 & 2 & 2 & 2 & 2 & 2 & \\
\hline
\end{tabular}


Table A1.3b. Pairwise community ecological relatedness measure ranging from a maximum value of 3 for community pairs sharing a biome and ecoregion to a minimum value of 1 for community pairs differing in biomes. Community or region name abbreviations are: Fort Severn (FSe), Mistissini (MI), Waswanipi (WA), Eastmain (EA), Waskaganish (WK), Chisasibi (CH), Whapmagoostui (WH), Wemindji (WE), Teslin (TE), Haines Junction (HJ), Old Crow (OC), Fort Good Hope \& Colville Lake (FGH \& CL), Fort Providence (FP), Fort Smith \& Fort Chipewyan (FSm \& FC), Kangiqsujuaq (KA), Hudson Bay (HB, including Akulivik, Puvirnituq, Inukjuak, Umiujaq, Kuujjuarapik), Hudson Strait (HS, including Ivujivik, Salluit, Kangiqsujuaq, Quaqtaq), Ungava Bay (UB, including Kangirsuk, Aupaluk, Tasiujaq, Kuujjuaq, Kangiqsualujjuaq), Sanikiluaq (SN), Qikiqtarjuaq (QI), Kugaaruk (KR).

\begin{tabular}{|l|c|c|c|c|c|c|c|c|c|c|c|c|c|c|c|c|c|c|c|c|c|}
\hline Community & Fse & MI & WA & EA & WK & CH & WH & WE & TE & HJ & OC & FGH \& CL & FP & FSm \& FC & KA & HB & HS & UB & SN & QI & KR \\
\hline Fse & & & & & & & & & & & & & & & & & & & & & \\
\hline MI & 2 & & & & & & & & & & & & & & & & & & & & \\
\hline WA & 2 & 3 & & & & & & & & & & & & & & & & & & & \\
\hline EA & 3 & 2 & 2 & & & & & & & & & & & & & & & & & & \\
\hline WK & 3 & 2 & 2 & 3 & & & & & & & & & & & & & & & & & \\
\hline CH & 2 & 2 & 2 & 2 & 2 & & & & & & & & & & & & & & & & \\
\hline WH & 2 & 2 & 2 & 2 & 2 & 3 & & & & & & & & & & & & & & & \\
\hline WE & 2 & 2 & 2 & 2 & 2 & 3 & 3 & & & & & & & & & & & & & & \\
\hline TE & 2 & 2 & 2 & 2 & 2 & 2 & 2 & 2 & & & & & & & & & & & & & \\
\hline HJ & 2 & 2 & 2 & 2 & 2 & 2 & 2 & 2 & 3 & & & & & & & & & & & & \\
\hline OC & 2 & 2 & 2 & 2 & 2 & 2 & 2 & 2 & 2 & 2 & & & & & & & & & & & \\
\hline FGH \& CL & 2 & 2 & 2 & 2 & 2 & 2 & 2 & 2 & 2 & 2 & 2 & & & & & & & & & & \\
\hline FP & 2 & 2 & 2 & 2 & 2 & 2 & 2 & 2 & 2 & 2 & 2 & 3 & & & & & & & & & \\
\hline FSm \& FC & 2 & 2 & 2 & 2 & 2 & 2 & 2 & 2 & 2 & 2 & 2 & 2 & 2 & & & & & & & & \\
\hline KA & 1 & 1 & 1 & 1 & 1 & 1 & 1 & 1 & 1 & 1 & 1 & 1 & 1 & 1 & & & & & & & \\
\hline HB & 1 & 1 & 1 & 1 & 1 & 1 & 1 & 1 & 1 & 1 & 1 & 1 & 1 & 1 & 3 & & & & & & \\
\hline HS & 1 & 1 & 1 & 1 & 1 & 1 & 1 & 1 & 1 & 1 & 1 & 1 & 1 & 1 & 2 & 2 & & & & & \\
\hline UB & 2 & 2 & 2 & 2 & 2 & 3 & 3 & 3 & 2 & 2 & 2 & 2 & 2 & 2 & 1 & 1 & 1 & & & & \\
\hline SN & 1 & 1 & 1 & 1 & 1 & 1 & 1 & 1 & 1 & 1 & 1 & 1 & 1 & 1 & 3 & 3 & 2 & 1 & & & \\
\hline QI & 1 & 1 & 1 & 1 & 1 & 1 & 1 & 1 & 1 & 1 & 1 & 1 & 1 & 1 & 2 & 2 & 2 & 1 & 2 & & \\
\hline KR & 1 & 1 & 1 & 1 & 1 & 1 & 1 & 1 & 1 & 1 & 1 & 1 & 1 & 1 & 2 & 2 & 3 & 1 & 2 & 2 & \\
\hline
\end{tabular}


Table A1.3c. Pairwise community geodesic distance $(\mathrm{km})$ estimated using the central latitude and longitude coordinates of each community. Community or region name abbreviations are: Fort Severn (FSe), Mistissini (MI), Waswanipi (WA),

Eastmain (EA), Waskaganish (WK), Chisasibi (CH), Whapmagoostui (WH), Wemindji (WE), Teslin (TE), Haines Junction (HJ), Old Crow (OC), Fort Good Hope \& Colville Lake (FGH \& CL), Fort Providence (FP), Fort Smith \& Fort Chipewyan (FSm \& FC), Kangiqsujuaq (KA), Hudson Bay (HB, including Akulivik, Puvirnituq, Inukjuak, Umiujaq, Kuujjuarapik), Hudson Strait (HS, including Ivujivik, Salluit, Kangiqsujuaq, Quaqtaq), Ungava Bay (UB, including Kangirsuk, Aupaluk, Tasiujaq, Kuujjuaq, Kangiqsualujjuaq), Sanikiluaq (SN), Qikiqtarjuaq (QI), Kugaaruk (KR).

\begin{tabular}{|c|c|c|c|c|c|c|c|c|c|c|c|c|c|c|c|c|c|c|c|c|c|}
\hline Community & Fse & MI & WA & EA & WK & $\mathrm{CH}$ & WH & WE & $\mathrm{TE}$ & HJ & oc & FGH \& CL & FP & FSm \& FC & KA & HB & HS & UB & SN & QI & KR \\
\hline \multicolumn{22}{|c|}{\begin{tabular}{|l|l|} 
Fse & \\
\end{tabular}} \\
\hline MI & 1106 & & & & & & & & & & & & & & & & & & & & \\
\hline WA & 1051 & 170 & & & & & & & & & & & & & & & & & & & \\
\hline EA & 727 & 381 & 334 & & & & & & & & & & & & & & & & & & \\
\hline WK & 782 & 355 & 269 & 97 & & & & & & & & & & & & & & & & & \\
\hline $\mathrm{CH}$ & 612 & 508 & 498 & 174 & 269 & & & & & & & & & & & & & & & & \\
\hline WH & 628 & 598 & 630 & 340 & 436 & 179 & & & & & & & & & & & & & & & \\
\hline WE & 663 & 444 & 419 & 92 & 187 & 82 & 253 & & & & & & & & & & & & & & \\
\hline TE & 2646 & 3752 & 3689 & 3373 & 3421 & 3252 & 3224 & 3309 & & & & & & & & & & & & & \\
\hline HJ & 2893 & 3997 & 3939 & 3620 & 3671 & 3495 & 3459 & 3553 & 272 & & & & & & & & & & & & \\
\hline$O C$ & 2926 & 3989 & 3965 & 3631 & 3700 & 3482 & 3407 & 3552 & 895 & 768 & & & & & & & & & & & \\
\hline $\mathrm{FGH} \& \mathrm{CL}$ & 2428 & 3503 & 3472 & 3140 & 3205 & 2995 & 2928 & 3063 & 709 & 754 & 511 & & & & & & & & & & \\
\hline FP & 1823 & 2927 & 2870 & 2550 & 2602 & 2425 & 2394 & 2483 & 830 & 1070 & 1261 & 766 & & & & & & & & & \\
\hline FSm \& FC & 1492 & 2598 & 2534 & 2219 & 2267 & 2101 & 2081 & 2155 & 1155 & 1407 & 1594 & 1089 & 350 & & & & & & & & \\
\hline KA & 1096 & 1250 & 1348 & 1115 & 1211 & 962 & 783 & 1034 & 3183 & 3378 & 3146 & 2728 & 2386 & 2147 & & & & & & & \\
\hline HB & 636 & 935 & 984 & 692 & 789 & 522 & 357 & 602 & 3027 & 3249 & 3133 & 2671 & 2202 & 1915 & 490 & & & & & & \\
\hline HS & 972 & 1317 & 1393 & 1124 & 1221 & 957 & 784 & 1036 & 2977 & 3174 & 2954 & 2529 & 2179 & 1943 & 206 & 440 & & & & & \\
\hline UB & 1145 & 940 & 1066 & 907 & 993 & 794 & 631 & 845 & 3487 & 3695 & 3505 & 3072 & 2673 & 2405 & 388 & 523 & 555 & & & & \\
\hline SN & 524 & 768 & 792 & 482 & 577 & 308 & 171 & 390 & 3070 & 3303 & 3239 & 2762 & 2241 & 1934 & 700 & 223 & 663 & 639 & & & \\
\hline QI & 1771 & 1985 & 2098 & 1879 & 1974 & 1726 & 1547 & 1798 & 3287 & 3432 & 3028 & 2705 & 2581 & 2432 & 764 & 1235 & 810 & 1051 & 1454 & & \\
\hline \begin{tabular}{|l|} 
KR \\
\end{tabular} & 1402 & 2196 & 2231 & 1913 & 2003 & 1740 & 1604 & 1822 & 2213 & 2365 & 2032 & 1656 & 1520 & 1416 & 1135 & 1262 & 961 & 1514 & 1439 & 1075 & \\
\hline
\end{tabular}




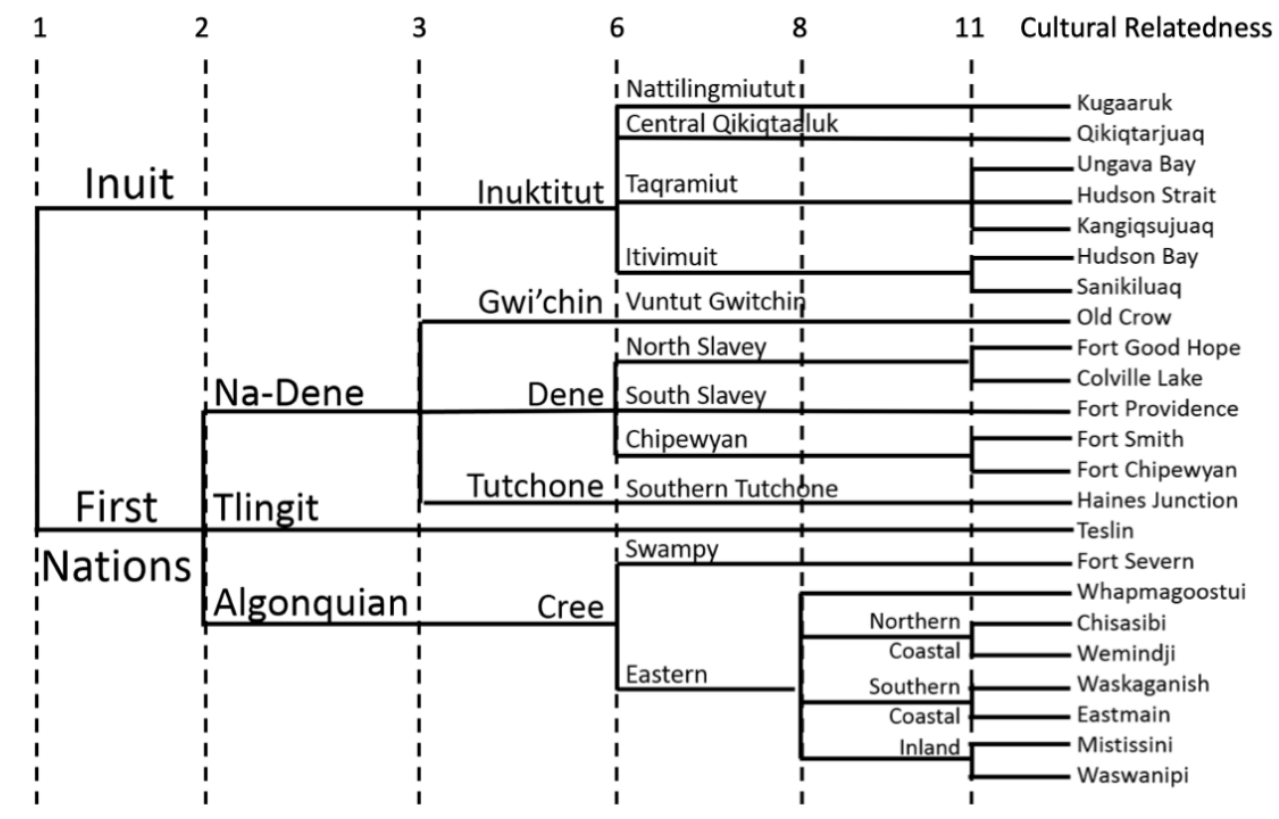

Fig. A1.1. Alternative measure of cultural relatedness used to assess whether conclusions are robust to inclusion of more and different levels of cultural and ecological differentiation. The cultural-linguistic terms and relationships used here are from the same source as the main analysis (Mithun 2001) but with more levels and groupings included here. The alternative ecological relatedness (ER) metric assigned ER $=1$ for coastal vs. non-coastal communities, ER $=2$ if coastal proximity was shared but biomes differed, ER $=3$ if coastal proximity and biomes were shared but ecozones differed and were non-adjacent, ER $=4$ if coastal proximity and biomes were shared and ecozones differed but were adjacent, and ER $=5$ if coastal proximity, biomes, and ecozones were all shared. 


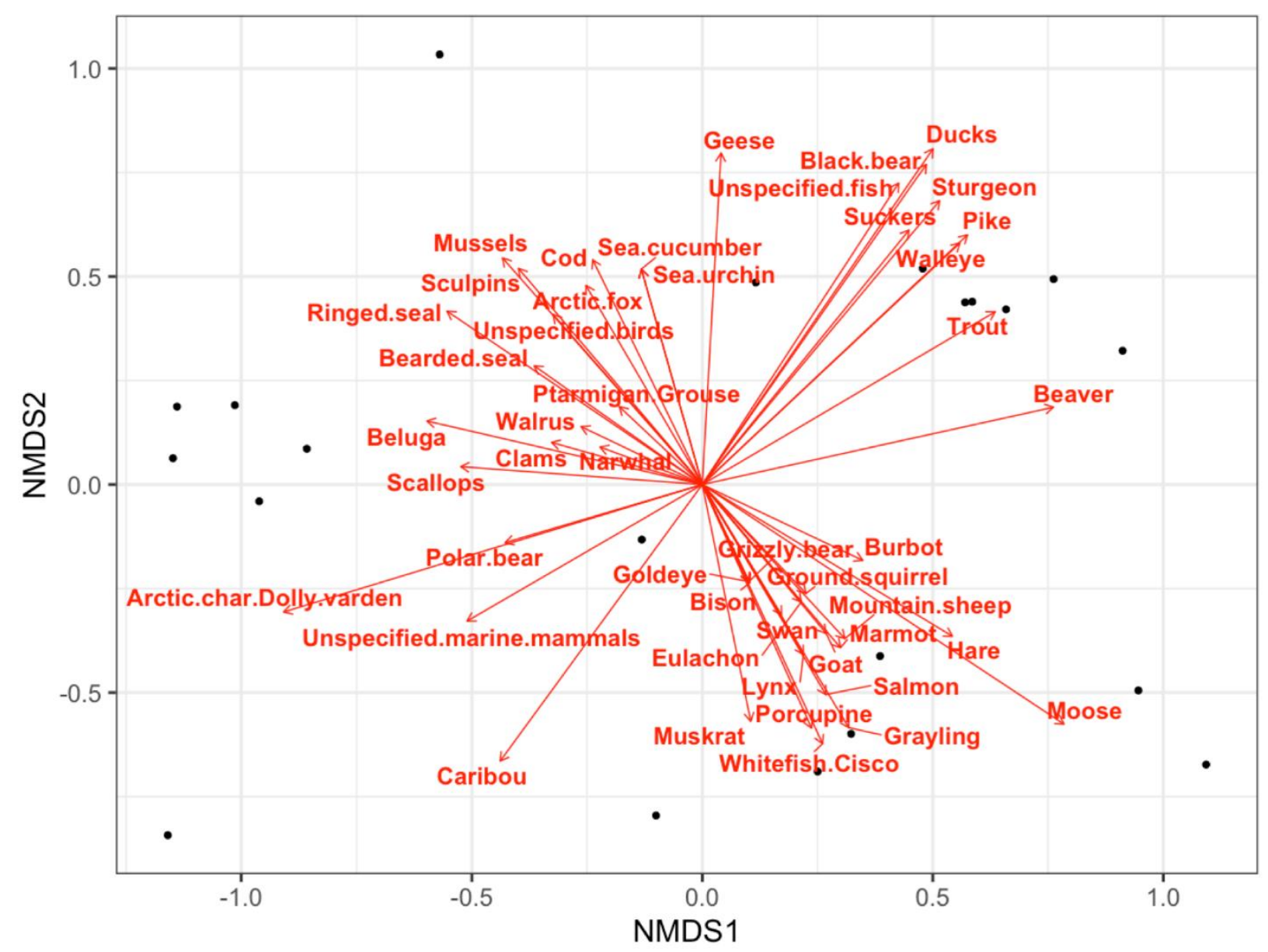

Fig. A1.2. Non-metric multidimensional scaling (NMDS) based on community-by-species standardized dietary importance matrix across 21 Indigenous communities or regional groups of communities and 45 species or groups of species. Communities are shown as black circles positioned along two NMDS axes of variation in the dietary importance of species consumed, with closer communities having more similar diets. Species are indicated as red vectors positioned according to how dietary importance of each species is correlated with each NMDS axis (longer vectors indicating stronger correlations). 


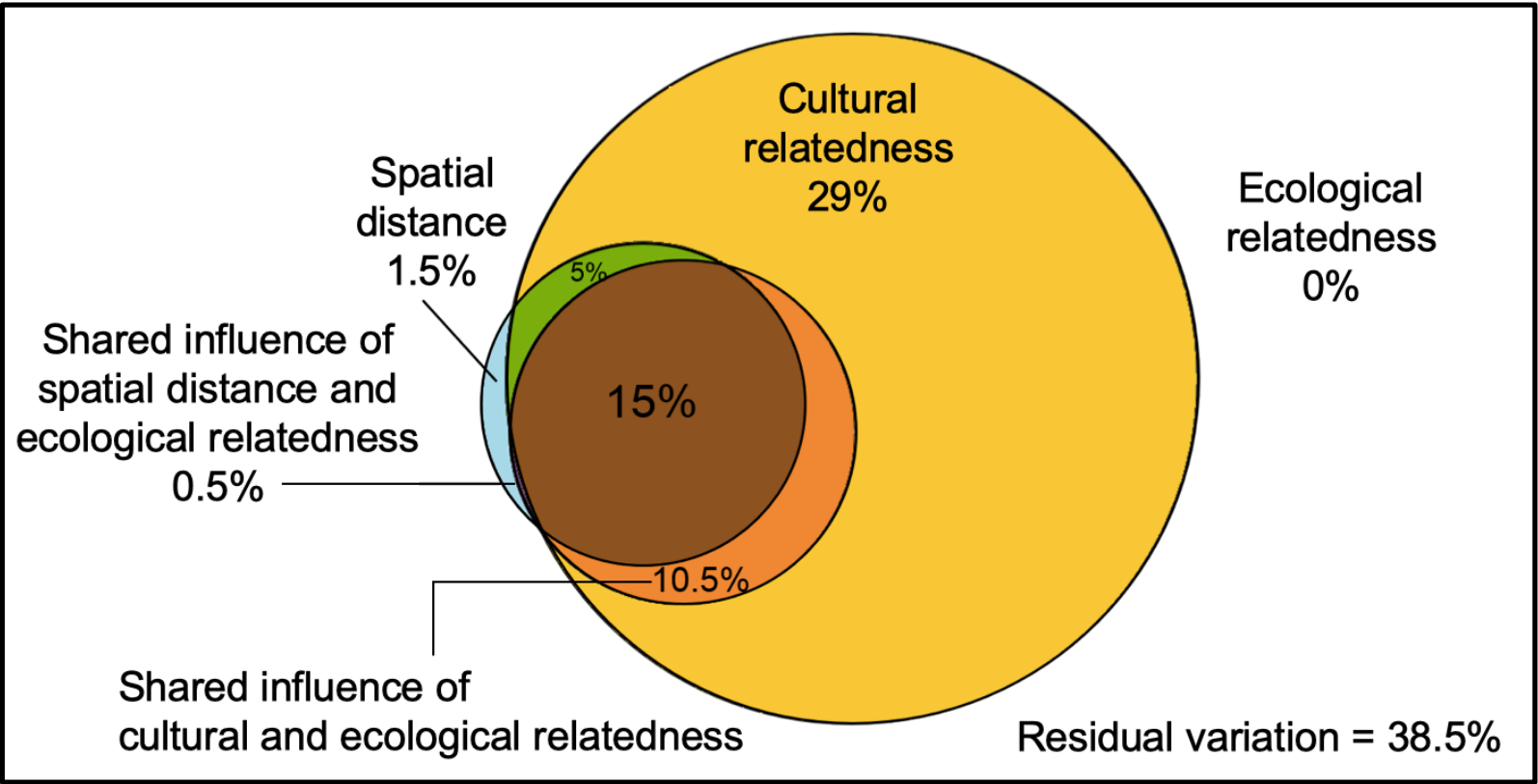

Fig. A1.3. Venn diagram summarizing variance partitioning of the predictive power of spatial distance combined with alternative measures of cultural and ecological relatedness. The alternative cultural relatedness metric is as presented in Fig. A1.1. The alternative ecological relatedness (ER) metric assigned $\mathrm{ER}=1$ for coastal vs. non-coastal communities, $\mathrm{ER}=2$ if coastal proximity was shared but biomes differed, ER $=3$ if coastal proximity and biomes were shared but ecozones differed and were non-adjacent, ER $=4$ if coastal proximity and biomes were shared and ecozones differed but were adjacent, and ER $=5$ if coastal proximity, biomes, and ecozones were all shared. Despite both alternative metrics being more detailed than those presented in the main text, the variance partitioning analysis using these alternatives had less explanatory power (residual variation $38.5 \%$ vs. 30\% for the analysis presented in the main text). At the same time, this alternative model reinforces the importance of culture as a predictor of diet similarity, with cultural relatedness contributing $59.5 \%$ of the $61.5 \%$ of the total variation explained by all three variables. The only predictive power not associated with cultural relatedness was $1.5 \%$ contributed independently by spatial distance and $0.5 \%$ contributed by a combination of ecological relatedness and spatial distance. 